\title{
Liquidity Funding Shocks: The Role of Banks' Funding Mix
}

Álvarez, Antonio, Alejandro Fernández, Joaquín García-Cabo, and Diana Posada

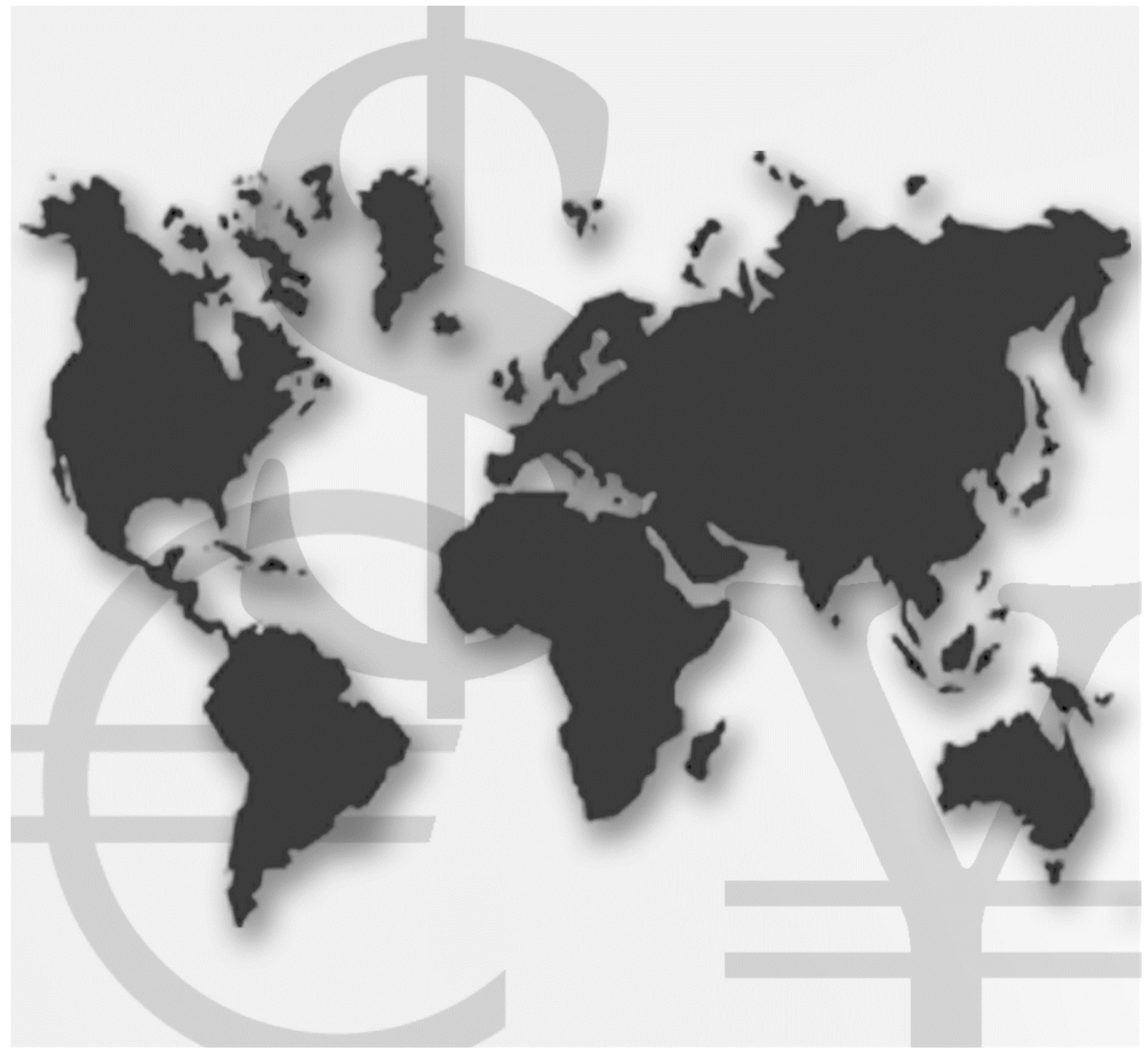

\section{International Finance Discussion Papers}

Board of Governors of the Federal Reserve System

Number 1245

April 2019 
Board of Governors of the Federal Reserve System

International Finance Discussion Papers

Number 1245

April 2019

\title{
Liquidity Funding Shocks: The Role of Banks' Funding Mix
}

\author{
Antonio Álvarez, Alejandro Fernández, Joaquín García-Cabo, and Diana Posada
}

NOTE: International Finance Discussion Papers are preliminary materials circulated to stimulate discussion and critical comment. References to International Finance Discussion Papers (other than an acknowledgment that the writer has had access to unpublished material) should be cleared with the author or authors. Recent IFDPs are available on the Web at www.federalreserve.gov/pubs/ifdp/. This paper can be downloaded without charge from the Social Science Research Network electronic library at www.ssrn.com. 


\title{
Liquidity funding shocks: the role of banks' funding mix*
}

\author{
Antonio Álvarez ${ }^{\dagger} \quad$ Alejandro Fernández ${ }^{\ddagger} \quad$ Joaquín García-Cabo ${ }^{\S}$ \\ Diana Posada 9
}

April 1, 2019

\begin{abstract}
This study attempts to evaluate the impact of an increase in banks' funding stress and its transmission to the real economy, taking into account different funding sources banks can rely on. Using aggregate data from eight Euro area financial systems, we find that following a liquidity funding shock, both credit and GDP decline in different amounts and lengths. GDP reverts faster than credit. Furthermore, periphery countries experience a more pronounced fall in deposits and credit growth and the negative effects from the shock last longer than in core countries. Banks' funding seems to play a relevant role as periphery countries rely more on wholesale funding during normal times.
\end{abstract}

Keywords: Liquidity funding shocks, ECB policy, Euro Area

JEL Classification: E50, E58, F45

\footnotetext{
*The views in this paper are solely the responsibility of the author(s) and should not be interpreted as reflecting the views of the Board of Governors of the Federal Reserve System or of any other person associated with the Federal Reserve System. The authors would like to thank participants at the 6th International Conference of the Financial Engineering and Banking Society for helpful discussions. We also thank two anonymous referees as well as the invited editor Ned Prescott for their insightful comments. Finally, we are grateful to Marta González Escalonilla for excellent research assistance.

†alvarez@uniovi.es, Universidad de Oviedo

$\ddagger$ afernandezc1@liberbank.es, Liberbank

$\S$ joaquin.garcia-caboherrero@frb.gov, Federal Reserve Board

\dposada@afi.es, Analistas Financieros Internacionales
} 


\section{Introduction}

The Global Financial Crisis (GFC) and the European sovereign debt crisis demonstrated the strong connection between monetary policy and financial stability, and showed that financial stress conditions can have an important impact on the real economy. These episodes of stress forced European banks to change their funding structures, especially for banks with weaker structural liquidity (i.e., those that display a low ratio of long-term stable funding sources to structural asset positions) and higher leverage in the pre-crisis period (van Rixtel and Gasperini (2013) and Vazquez and Federico (2015)). In response to this, during the GFC many central banks adopted expansionary monetary policies in order to achieve financial stability, allay deflationary fears, and promote economic growth. Official interest rates were brought down to the zero lower bound across the board, and major central banks expanded their balance sheets by purchasing securities or by providing ample liquidity to the banking sector. These unconventional monetary policies resulted in a price increase of those securities and a reduction in their yields, as well as a decline in market risk premium and banks' funding stress.

In particular, the European Central Bank (ECB) launched a series of unconventional measures to ensure the effective transmission of the monetary policy stance to the real economy. However, at some point the ECB will taper off these unconventional measures and banks will therefore have to rely on their traditional wholesale funding sources, such as the interbank market. The transition from an environment of excess liquidity could make banks more vulnerable to funding shocks and possibly force the ECB to step in again. In this paper, we analyze the liquidity channel of financial transmission through which liquidity funding shocks spread to banks' funding mix as well as to the real economy (BIS (2011)).

The impact of liquidity funding shocks on the banks' liability side has been increasingly studied in the literature (Baglioni (2012)) but mainly with bank-level data, such as de Haan and van den End (2013) and de Haan et al. (2017). This paper contributes to this growing literature by analyzing, using a macroeconomic approach, how aggregates of banks' funding sources and macroeconomic variables adjust to a liquidity shock in the interbank market. In addition, we want to investigate how this shock could affect credit availability and if the impact on credit volumes will be short lived or more persistent over time.

For this purpose, we estimate a panel VAR for eight countries in the Euro area (Austria, Belgium, France, Germany, Ireland, Italy, Portugal, and Spain) for the period 2003:Q1-2015:Q4, in which we distinguish between core and periphery countries. We use aggregate data for each country's financial system. To our knowledge, this is the first study to apply a panel VAR approach to a sample of Euro area countries and to address the effects of wholesale funding shocks at a country level. Most of the studies addressing the effects of liquidity funding shocks have been carried out in a micro framework using bank-level data. Although this framework 
allows the richness of the disaggregated data to be exploited, it does not permit an analysis of the implications for GDP and credit growth. Taking into account the evolution of these variables allows for better measurement of the effects of ECB policies on the real economy.

Our results show that wholesale liquidity funding shocks cause banks to adjust their funding mix through an increased reliance on the ECB and a decline in wholesale market funding. Moreover, this shock causes a relatively persistent impact on loan growth. There is a heterogeneous response of core and periphery countries that could be explained by the composition of banks' funding as well as the soundness of a country's financial system. This findings have important implications for financial regulation and macroprudential policy since they point towards the need to implement minimum capital requirements or similar measures to assure financial soundness.

The paper is structured as follows. In section 2, some stylized facts are presented. Section 3 contains a literature review. Section 4 presents the data and section 5 covers the model. In section 6 , we discuss the findings of the empirical model. In section 7 , we check the robustness of the results. Finally, section 8 concludes the paper.

\section{Monetary policy responses to the crisis}

As a result of the 2007-08 subprime crisis and the 2011 European sovereign debt crisis, liquidity in the interbank market dried up, and banks' access to market-based funding became severely impaired. Normally, the interbank market operates smoothly, with interest rates for unsecured interbank loans being only marginally higher than rates on secured interbank loans or on central bank loans. In these two crisis episodes, however, the funding through interbank markets was severely impaired, with rising interest rates and increased liquidity hoarding by banks.

A traditional measure to assess the health of the interbank market is the Euribor- Overnight Index Swap (OIS) spread. A higher spread is typically interpreted as a signal of decreased willingness to lend by major banks, while a lower spread indicates higher liquidity in the market. As such, the spread can be viewed as an indicator of banks' perception of the creditworthiness of other financial institutions and the general availability of funds. Figure 1 shows the evolution of the 3-month Euribor-OIS spread over the last decade. Before the GFC, money markets were functioning smoothly. Spreads were broadly stable and quite low, with little dispersion across counterparties, and the market was liquid, especially at the short end. The Euribor-OIS spread hovered below 10 basis points. However, following the outbreak of the financial crisis of 20072008, the spread spiked to an all-time high of 197 basis points in October 2008, due to higher perceived credit risk among banks. In order to prevent market-wide liquidity problems that could threaten financial stability, major central banks introduced measures to provide large liquidity to the banking sector.

In particular, in October 2008 the ECB introduced the fixed-rate-full-allotment (FRFA) tender 


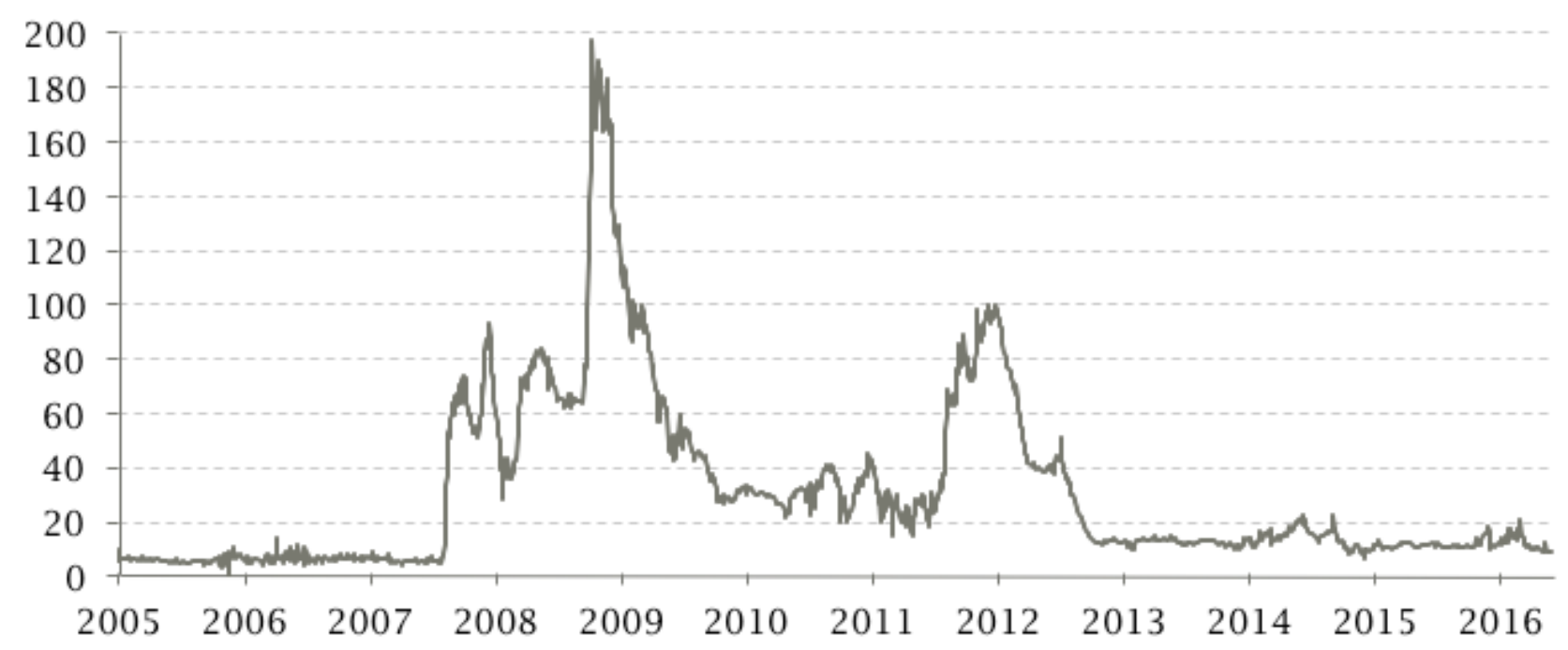

Fig. 1 Euro area interbank rate spread. 3-month Euribor rate - 3-month OIS rate (in basis points). Source: Thomson Reuters

procedure. As a consequence, the spread declined substantially, dropping below 100 basis points in mid-January 2009. However, in the second half of 2011, signs of stress in interbank markets resurfaced intensively. The tensions in sovereign debt markets in the Euro area spread from smaller peripheral countries - Greece, Ireland and Portugal - to Italy and Spain, and funding pressure on banks in the stressed countries mounted. The December 2011 and the February 2012 LTROs $^{1}$ conducted by the ECB helped allay fears over banks' funding pressure, thus leading to a substantial easing of financial conditions and a reduction of the interbank rate spread.

Partly, as a result of these interbank market tensions, credit availability for households and nonfinancial firms became severely impaired. Financial institutions tightened lending standards and credit flows to both households, and firms experienced significant declines, thus dragging down nominal growth. Following the two aforementioned episodes of financial stress, private credit growth turned negative, especially for the nonfinancial corporate sector. This decline in private credit growth not only reflects supply-side factors (such as increasing funding difficulties or capital shortfalls for banks), but also demand-side factors (such as a deterioration in the prospects for the economy, and notably the housing market). For instance, Bernanke and Lown (1991) show that both reduced credit supply as well as weak demand effects played a major role in the US recession of 1990. Altavilla et al. (2015) find that tighter bank loan supply to nonfinancial corporations led to a protracted contraction in credit volumes and higher bank lending spreads.

\footnotetext{
${ }^{1}$ Long-term refinancing operations were introduced in June 2009 to support bank lending and liquidity in the Euro area money market.
} 
These episodes of stress forced banks in the Euro area to change their funding structures. Before the crisis, banks worldwide had increasingly used wholesale funding repurchase agreements (repos), brokered deposits, interbank loans, and commercial paper to supplement retail deposits (Feldman and Schmidt (2001)). However, as a result of limited access to private short-term wholesale and interbank markets, banks in the Euro area were forced to reduce sharply their reliance on wholesale funding sources: i.e., the sum of deposits from other deposit-taking corporations, money market fund shares and total debt securities issued by Euro area residents. In a liquidity crisis, central banks typically respond by lending to banks that are illiquid but solvent, against good collateral. Playing its role as lender of last resort, the ECB took over the liquidity provision task of the interbank market. The ECB's liquidity provision made financial institutions more reliant on funding from the Euro system. This increasing reliance on ECB's funding was particularly relevant in the most stressed countries. For instance, in June 2012 banks in Spain accounted for $51 \%$ of the lending to Euro area financial institutions by the ECB, although Spain only accounted for $12 \%$ of the Euro area's GDP. Since the peak of the sovereign debt crisis in the summer of 2012, the improvement in financial conditions has allowed banks to reduce steadily their holdings of Euro system funds.

However, ECB's monetary policy stance is still extremely accommodative. The size of the Euro system's balance sheet has increased from 1.5tr euros in 2007 to more than 3tr euros in 2016. Thus, Euro area banks are operating in an environment of easy financial conditions and excess liquidity. This is contributing to the recovery of credit flows and ultimately economic growth in the Euro area. One relevant question for financial institutions and policymakers is to analyze the impact of another episode of wholesale funding liquidity stress on banks' funding structures, lending activity and the real economy.

As a result of the crisis, Euro area banks were under pressure due to rising levels of nonperforming assets (NPAs), which caused losses that eroded dramatically banks' capital bases. As a response to the financial crisis, supervisors and regulators have all aimed at improving banks' capital adequacy. However, in order to strengthen solvency positions, capital-constrained banks became increasingly reluctant to approve new lending, which further aggravated the economic situation. In principle, when a bank needs to improve its capital ratio, it can do so by reducing assets or by raising new equity capital, diluting existing shareholders. As shown by Hyun and Rhee (2011), banks prefer to reduce assets due to the high cost of equity.

European banks have experienced significant reductions in their asset base, while boosting their capital ratios since 2011. Since the peak in May 2012 to February 2017, EU banks have decreased the size of their balance sheets by $10 \%$, which translated to a contraction in loans to the private sector, thus primarily affecting stressed Euro area countries. In the same time span, the volumes of capital and reserves increased by $11 \%$. The next section covers the fast-growing literature on the analysis of the effects of wholesale and monetary policy shocks on the economy. 


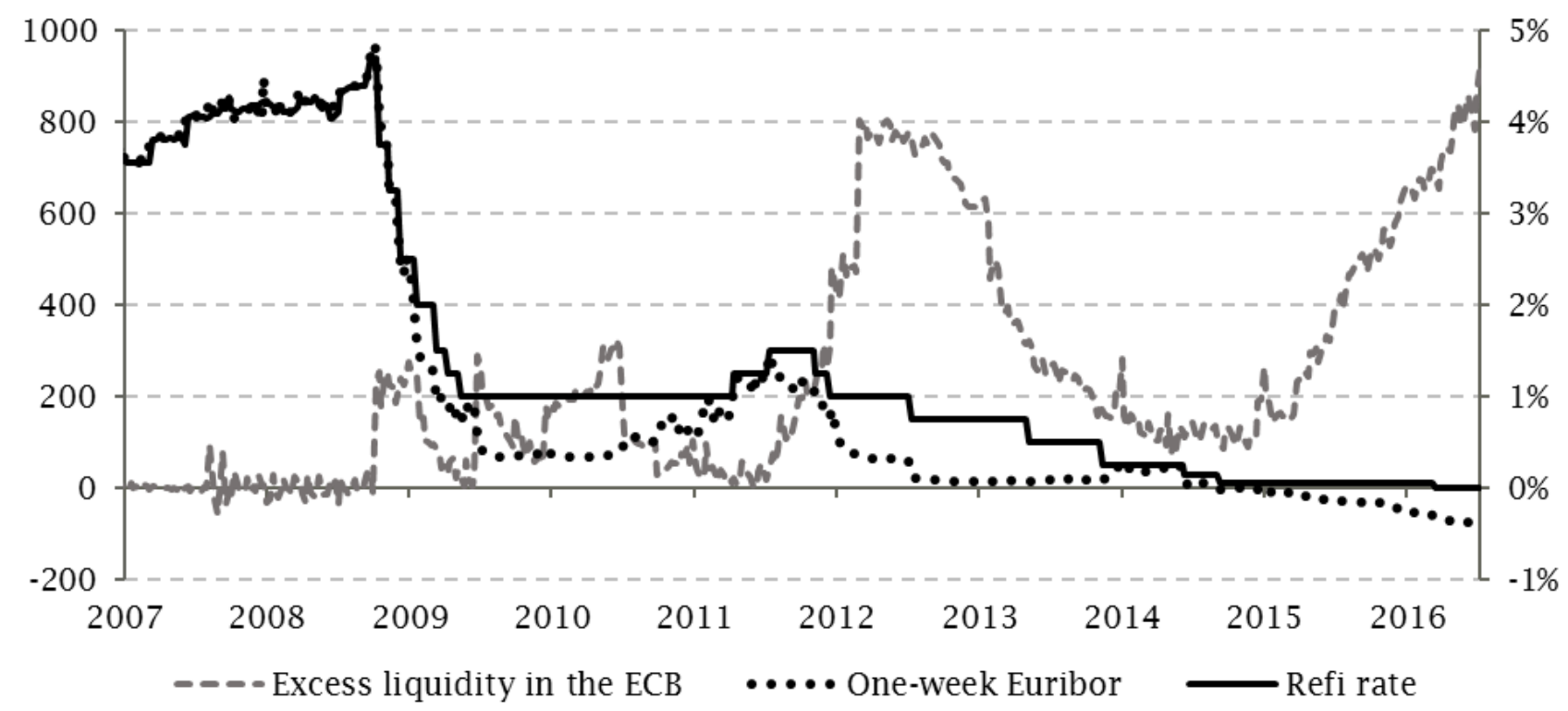

Fig. 2 Excess liquidity (billions of euros) and short-term interest rates in the Euro area. Excess liquidity is defined as deposits at the deposit facility net of the recourse to the marginal lending facility, plus current account holdings in excess of those contributing to the minimum reserve requirements. Source: ECB.

\section{Literature review}

Our paper relates to two main strands of literature. The main one focuses on the growing literature on the macroeconomic effects of liquidity funding shocks using multivariate econometric models. In particular, VAR models with macro and financial variables have been increasingly used in order to identify the effect of monetary policy shocks on the economy. Following previous literature (Bernanke and Gertler (1995); Christiano et al. (1996) and Christiano et al. (2000)), the monetary policy shock is usually identified by means of the overnight rate and a specific ordering of variables. Ciccarelli et al. (2013) and Ciccarelli et al. (2014) estimate a panel-VAR including variables from the ECB's Bank Lending Survey at country level and found that the credit channel might act as an amplification mechanism for the impact of monetary policy on the real economy, especially in stressed countries. Using a similar econometric framework, DarracqParies and Santis (2015) find that tighter bank loan supply to firms leads to lower credit volumes and higher bank lending spreads, thus fostering firms to substitute bank loans with debt securities issuance. Bijsterbosch and Falagiarda (2014) model credit supply effects in Euro area countries with a time-varying parameter VAR. The results show that credit supply shocks have been a key driver of business cycle fluctuations in many Euro area countries, especially in the recent crisis. Giannone et al. (2012) analyze the impact on the economy of the ECB's unconventional 
monetary policy implemented in the aftermath of the collapse of Lehman Brothers in 2008, based on aggregate bank data. Their simulations of a VAR model show that bank loans to households and, in particular, to nonfinancial corporations are higher than would have been the case without the ECB interventions.

Focusing on the US, Gilchrist and Zakrajsek (2012) show that a decrease in the credit supply caused by worsening in the banks' capital position led to an increase in the cost of debt (via a widening of credit spreads) and a subsequent fall in spending and production. Bassett et al. (2014) use information from the Senior Loan Officer Opinion Survey collected by the Federal Reserve to construct a credit supply indicator. Lown and Morgan (2006) studied the macroeconomic impact of a shock to lending standards using information contained in the same survey.

From a micro-level standpoint, de Haan and van den End (2013) model Dutch banks' responses to liquidity funding shocks. They analyze three types of adjustment on the asset side of the bank balance sheet: i.e., adjustments of lending, liquidity hoarding, and fire sales. The dynamics of the bank reactions are modeled in a panel VAR framework. They report that in response to funding shocks banks reduce lending, especially wholesale lending. In a related paper using micro data from 181 euro banks, de Haan et al. (2017) analyze banks' adjustments of loan volumes and lending rates in response to liquidity funding shocks in a panel VAR framework. They find that shocks in the securities and interbank markets have significant effects on lending rates and supply, particularly in banks of stressed countries.

A second strand of related literature focuses on the role of wholesale funding. In general, before the crisis the literature contended that banks' increasing reliance on wholesale markets was positive. Unlike retail depositors, the providers of wholesale funding had an incentive to monitor banks, thus limiting risk taking (for example, Calomiris and Kahn (1991); Rochet and Tirole (1996), because they were not protected by deposit insurance schemes. However, the crisis provided evidence that funding characteristics matter for bank distress and wholesale funding can be a source of instability (IMF (2013)), as wholesale funding made the financial system more interconnected and complex (Brunnermeier and Pedersen (2009); Farhi and Tirole (2012)) and collective withdrawals triggered funding disruptions during crisis (Brunnermeier and Oehmke (2013), Goldsmith-Pinkham and Yorulmazer (2010)).

From a more theoretical point of view, Dietrich and Vollmer (2010) study interbank markets in an international context. Freixas and Holthausen (2005) show that interbank market integration may fail when cross-border information about banks is less precise than home country information. More empirically, Afonso et al. (2011) examine the unsecured overnight market in the United States and show that market activity shrinks considerably after the bankruptcy of Lehman Brothers, but it does not collapse completely. The shrinking appears to be caused mostly by a withdrawal of supply. Brunetti et al. (2011) use data from the Italian e-MID market to examine whether central bank interventions improved liquidity in the interbank market. They 
find that public injections of liquidity increase overall uncertainty, as measured by higher market volatility and higher spreads. They find that asymmetric information is not mitigated by ECB interventions.

This literature review highlights the growing academic interest in analyzing the impact of wholesale funding shocks on economic activity and banks' behavior. The main contribution of our paper is that, unlike other papers that use bank-level data, we use data at the country level to address the question of the possible effects of a wholesale funding shock on the Euro area economy, particularly on the aggregate lending by the banking sector of different countries.

\section{Data}

We use quarterly data for eight Euro area countries over the period 2003:Q1-2015:Q4: Austria (AUT), Belgium (BEL), France (FRA), Germany (GER), Ireland (IRL), Italy (ITA), Portugal (POR), and Spain (ESP). We restrict to Euro area countries as they have a common monetary policy, so that we can better disentangle the effects of the transmission of such policy into the real economy through the liquidity channel.

Our dataset ${ }^{2}$ includes real GDP $(G D P)$ and inflation proxied by the GDP deflator $(\pi)$ to control for macroeconomic conditions. We also take into consideration how liquidity shocks are transmitted into the financial sector and the banks' funding mix. For this purpose we include loans (Loans) and deposits (Deposits) from households and non-financial corporations, wholesale markets funding (Wholesale), defined as deposits from other deposit-taken corporations from the liabilities of the balance sheet of Euro area MFIs, and funding from the Euro system $(E C B)$ (deposits from the Euro system in the balance sheet of Euro area MFIs) since the latter can act as a liquidity buffer in times of stress, as has been the case since the beginning of the GFC. By relating this with retail deposits and wholesale funding, the link between liquidity hoarding and funding sources can be investigated.

To identify the stress in the interbank market we use the Euribor-OIS spread (Spread): i.e., the difference between the rate at which European banks lend to each other (Euribor) and the overnight risk-free swap rate (EONIA) among the same banks in a 3-month period. This variable broadly captures the market funding cost and is generally considered to be an important determinant of banks' deposit and lending rates. Moreover, the spread captures the effect of the

\footnotetext{
${ }^{2}$ Data corresponding to GDP and GDP deflator were collected from Eurostat according to the ESA10 procedure. All data are in annual growth rates. All countries presented seasonally adjusted data, except for Ireland which only provides non-seasonally adjusted data. Hence, we apply annual growth rates to all series to control for any sort of seasonal effect. Financial aggregates were taken from the ECB aggregated balance sheet of Euro area MFIs (excluding the Euro system) published in the Statistical Data Warehouse of the ECB. Euribor-OIS spread is taken from Thomson-Reuters Datastream.
} 
unconventional monetary policy measures used by the ECB through the EONIA rate (Ciccarelli et al. 2013).

Finally, we control for country risk including the 10-year sovereign bond yield (Bond) and for the strength of financial institutions (i.e., solvency) in each country by using a proxy for the aggregate capital ratio across all banks. To do so, we use an aggregate ratio of assets-to-capital where assets are not risk weighted, known as the leverage ratio (Leverage). Although this differs from the definition of banks' capital ratio, used in regulatory standards, it allows us to use data over a longer period and may provide a more faithful representation of banks' leverage. This group of variables allows us to study how liquidity shocks are transmitted to credit and GDP growth. Some summary statistics are presented in Table 1.

Table 1 Summary statistics for the period 2003:Q1-2015:Q4. All variables are in percentage terms. 1 Annual average growth rate. 2 Loans and deposits refer to the aggregate of households and non-financial corporations. 3 The ratio was calculated using total loans and deposits. 4 Assets were taken from the aggregate balance sheet of Euro Area MFIs.

\begin{tabular}{lllllllll}
\hline & GER & FRA & ITA & ESP & POR & AUT & BEL & IRL \\
\hline GDP (1) & 1.32 & 1.05 & -0.20 & 0.97 & 0.10 & 1.39 & 1.46 & 2.70 \\
GDP deflator (1) & 1.29 & 1.37 & 1.60 & 1.57 & 1.66 & 1.81 & 1.68 & 0.61 \\
Loans (1) (2) & 0.38 & 5.14 & 4.35 & 5.13 & 2.01 & 3.50 & 3.08 & 3.48 \\
Deposits (1) (2) & 4.05 & 4.86 & 6.11 & 5.37 & 3.97 & 3.98 & 5.80 & 5.24 \\
Loans to deposits ratio (3) & 104.0 & 113.6 & 120.1 & 102.5 & 109.5 & 109.2 & 85.2 & 99.4 \\
Loans (\% assets) (2) (4) & 59.5 & 52.5 & 63.7 & 65.0 & 63.1 & 60.0 & 47.1 & 36.9 \\
Deposits (\% assets) (2) (4) & 57.4 & 46.2 & 54.2 & 64.3 & 58.7 & 54.9 & 55.3 & 37.3 \\
ECB funding (\% assets) (4) & 1.80 & 0.84 & 2.59 & 3.57 & 4.65 & 1.25 & 2.43 & 3.93 \\
Wholesale funding (\% assets) (4) & 18.40 & 22.38 & 17.21 & 12.51 & 12.48 & 20.72 & 13.03 & 17.77 \\
\hline
\end{tabular}

Average annual GDP growth rates ranged from a low of $-0.2 \%$ in Italy to a high of $2.7 \%$ in Ireland, whereas the GDP deflator displayed less dispersion among countries, staying below ECB's $2 \%$ inflation target. On average, deposits grew slightly more than loans in our sample. The last five rows of Table 1 show statistics of variables describing the banking sector's balance sheet composition. The loan-to-deposit ratio is used to assess a bank's liquidity by comparing a bank's total loans to its total deposits. Italy displays the highest loan-to-deposit ratio, while Belgium has the lowest one. In terms of the weight of loans and deposits in total assets, Ireland shows the lowest weight. The variable ECB funding shows banks' reliance on ECB's funding facilities. Note that peripheral countries have the highest proportion of ECB-funded liabilities. As for the reliance on wholesale funding sources, Austria, France and Germany exhibit the greatest proportion of this source of funding. 


\section{Empirical Model}

We use a panel-data vector autoregression model ( $\mathrm{p}$-VAR). This methodology follows the vector autoregression approach, treating all variables in the system as endogenous, and incorporates the panel dimension of the data which allows to control for unobserved heterogeneity. We estimate a first order p-VAR model as follows:

$$
Y_{i, t}=A_{i}+B Y_{i, t-1}+\varepsilon_{i, t}
$$

where $Y_{i, t}$ is a vector containing macro-economic variables and financial systems' balance sheet information for each country $i$ and quarter $t$. We use combinations of the nine variables described in the previous section to estimate different models, as we wish to compare results for different models, and we also extend the number of lags in the model. We present all the different specifications in the next sections. In order to ensure stationarity of the series we define each variable in annual growth rates, except for the spread which is expressed in levels. From now on, we refer to variables preceded by $\triangle$ as the growth rate of the original series.

$A_{i}$ is a vector of country-specific intercepts, $B$ is a matrix polynomial in the lag operator of order one according to the Akaike information criterion and the Schwarz information criteria (SBIC), and $\varepsilon_{i}$ contains the error terms for every left-hand side variable. In section 7 we show that the main results of our model are robust to alternative lag specifications. One advantage of this approach is that given the relatively short quarterly time series available for Euro area countries, the panel VAR allows us to have a larger number of degrees of freedom.

We estimate the coefficients of the p-VAR by system Generalized Method of Moments (GMM), using lags of the model variables as instruments. ${ }^{3}$ There are two sets of instruments in the model: the first set deals with the endogeneity of the regressors while the second deals with the correlation between the lagged dependent variables and the error terms. In particular, fixed effects are correlated with the regressors due to the inclusion of lags of the dependent variables, so eliminating fixed effects by mean-differencing would result in biased coefficients. We use a Helmert transformation (forward mean-differencing) procedure instead (Arellano and Bover (1995)), which removes only the mean of all future observations for each country-quarter. Lagged regressors can be used as valid instruments for estimating the coefficients using system GMM, since this procedure preserves the orthogonality between transformed variables and lagged regressors (see for instance de Haan and van den End (2013)).

To examine the financial system's response to a variety of economic shocks, we use impulseresponse functions derived from the estimated p-VAR model, presented in Table A1 in the Appendix. Our identification strategy relies in a Cholesky structure over $\varepsilon$ to achieve orthogonal

\footnotetext{
${ }^{3}$ We thank Love and Zicchino (2006) and Abrigo and Love (2016) for their Stata code, and we refer to them for further details.
} 
structural shocks. This structure implies an exogeneity ordering among the variables. The first variable is the most exogenous, affecting the following variables contemporaneously, while the last one affects the other variables only with lags.

Following Uribe and Yue (1996) we include $\triangle G D P$ and $\triangle \pi$ as the most exogenous variables, where $\triangle G D P$ is the gross domestic product and $\triangle \pi$ reflects inflation in a particular country at a given time. For the remaining variables, we think it is a reasonable assumption that banks react earlier to macroeconomic conditions through their lending channel than through consumer deposits. Lastly, we assume that the markets react through the changes in the yield of the treasury bond and the ECB provides liquidity after observing the state of the economy and the evolution of banks' balance sheets, hence they are the most endogenous variable. We assess the robustness of this ordering in section 7 by altering the order of the variables and analyzing the effect on the impulse responses.

Since we construct impulse-response functions from the p-VAR estimated coefficients, it is necessary to take into account the standard errors from these estimates. We calculate standard errors and construct confidence intervals on the impulse-response functions using Monte Carlo simulation. In particular, we conduct 1000 random draws of the model's coefficients, using the estimated coefficients and their variance-covariance matrix, to construct $90 \%$ confidence intervals for the impulse-responses.

\section{Results}

This section illustrates the results of our estimation in the form of impulse response functions. We start by testing the performance of what we define as the baseline model. In particular the baseline model in equation (1) is a first order p-VAR, where $Y_{t}$ is an eight-variable vector for each of the 8 countries analyzed, such that: ${ }^{4}$

\section{$[\triangle G D P \quad \triangle \pi \quad \triangle \text { Loans } \triangle \text { Deposits Spread } \triangle \text { Wholesale } \triangle \text { Leverage } \triangle E C B]^{\prime}$}

To do so, we study the response of our variables to a one standard deviation shock in GDP growth. Figure A1 in the Appendix shows the impulse responses for all the variables to this shock. GDP growth increases by 1\%, and the effect dies out after 10 quarters. Following this shock, credit growth accelerates on impact and it plateaus after ten quarters, in line with the existing empirical evidence of credit procyclicality. Deposits follow a similar path increasing on impact (though less than credit did), raising the need of banks to find alternative funding sources. Thus, wholesale and ECB funding growth follow the same trajectory as the credit expansion. Since we feel comfortable

\footnotetext{
${ }^{4}$ The baseline model is chosen given the limitation of our time series to 48 quarters. The fact that the estimation uses lags as instruments reduces the number of degrees of freedom when estimating the sub-samples. Moreover, it is not feasible to estimate the extended model with 9 endogenous variables with additional lags.
} 
with our estimation, we proceed to analyze the role of banks' funding mix during liquidity crises and its effects on GDP and credit growth.

In the past, liquidity crises have materialized in the form of an increase in the Euribor-OIS spread. We study the effect of a shock in the spread variable for the whole panel and repeat the p-VAR estimation of this baseline specification for two sub-samples of countries: core (Austria, Belgium, France and Germany) and periphery countries (Ireland, Italy, Spain and Portugal). This exercise allows testing for differences in responses by groups of countries to similar shocks, i.e., the effect of ECB intervention in Central Europe compared to Southern Europe. In Section 7 we analyze the predictions of the model with the yield of the national treasury bond as an additional endogenous variable and show that the results are quantitatively similar. We now turn to describe the results for the whole panel and for the sub-samples through an analysis of the impulse responses of the variables to a shock to the spread and evaluate how the transmission of the shock differs in both groups.

\subsection{Liquidity shock}

The cumulative impulse response of deposits, wholesale and ECB funding to a one standard deviation increase (20 basis points) of the Euribor-OIS spread after 10 quarters is presented in Table 2 . When interbank market stress appears, i.e., funding becomes more costly for banks, we observe that wholesale market volumes fall significantly. Relative to the sample average growth ${ }^{5}$ of wholesale funding of $1.25 \%$, these results imply up that after 10 quarters it remains at an interannual growth of $-7.7 \%$, or 0.089 percentage points below its average growth. The average growth rate for wholesale funding in 2010 averaged $-10 \%$, so relative to the sample average our results are in line with the data. Wholesale funding demand falls both in core and periphery countries, though it is much more pronounced in the latter ones, with wholesale funding still 0.21 percentage points below its average growth two and a half years after the shock.

The reason for this major stress in the periphery banking system may be due to the banks' behavior during credit expansions. Credit expansions exert a significant negative influence on banks' solvency since, on average, banks do not increase their capital buffers in accordance with the additional risk they are undertaking. For example, before the GFC, credit grew more strongly in periphery countries than in core countries (16.4\% quarterly growth compared to $5.3 \%$ between 2004 and 2007), but banks' capital buffers were significantly smaller in the periphery. While core countries' leverage ratio decreased from 2003 to 2008 by 0.24 percentage points, in the periphery this measure increased by 0.76 percentage points, suggesting that additional regulatory measures should be undertaken in order to assure financial soundness.

\footnotetext{
${ }^{5}$ These results are interpreted in this example relative to the sample average growth of variables for the whole sample, as an approximation to a stationary growth path.
} 
Our results also show the different dynamics followed when interbank stress appears. In that case, banks need to change their funding mix and rely more on other funding sources such as deposits or ECB funding. Deposits (households and non-financial corporations) have proven to be a very stable source of funding for banks, so it is difficult for them to raise a larger amount fast enough to solve liquidity problems. In fact, four quarters after the initial shock deposits remain fairly invariant and then they start to decelerate at a very slow pace. After ten quarters, deposits have barely changed. To put the results in context, deposit growth averaged $4.92 \%$ increase between 2003:Q1-2015:Q4 for the whole sample, so we can interpret the effect of the shock to reduce growth to $3.72 \%$, or a 0.012 percentage point decrease after 10 quarters.

Different behaviors are observed in core and periphery countries that are consistent with the data. In the former countries, deposits remain relatively stable while in the latter deposits show a decelerating trend five times bigger: $-1.24 \%$ from an average growth of $5.16 \%$, or a 0.06 percentage point decrease ten quarters after the shock. The different response of deposits between periphery and core countries provide an external validation of the model vis-à-vis the observed behavior in deposits during the GFC in Europe. While Portugal and Ireland suffered large deposit losses in 2011 (13\% and 6\%, respectively), Germany attracted 10\% more depositors. These patterns can be the result of two effects: divergent savings patterns between core and periphery countries ${ }^{6}$ and the escape of foreign investors from the periphery towards more stable economies. The decrease in deposits held at the banking system in periphery countries took a toll on the recovery of these countries, with long-lasting effects through a weakened banking system and reduced credit growth. The model is successful in disentangling how the effect of a shock to the spread is transmitted to the real economy and the financial sector.

Table 2 Cumulative response to a spread shock. Core countries: Austria, Belgium, Germany and France. Periphery countries: Italy, Ireland, Portugal and Spain. Cumulative responses are expressed in percentage point differences.

\begin{tabular}{lccccccccc}
\hline & \multicolumn{3}{c}{ Deposits } & \multicolumn{3}{c}{ Wholesale } & \multicolumn{3}{c}{ ECB } \\
\hline Quarter & All & Core & Periph & All & Core & Periph & All & Core & Periph \\
\hline \hline 4 & 0.010 & 0.006 & -0.012 & 0.044 & 0.022 & 0.064 & 0.465 & 0.734 & 2.055 \\
6 & 0.010 & 0.010 & -0.021 & 0.016 & -0.003 & 0.010 & 0.417 & 0.599 & 2.741 \\
8 & 0.002 & 0.013 & -0.037 & -0.034 & -0.025 & -0.083 & 0.262 & 0.338 & 3.108 \\
10 & -0.012 & 0.016 & -0.064 & -0.089 & -0.034 & -0.211 & 0.213 & 0.114 & 3.479 \\
\hline
\end{tabular}

As a consequence of scarce liquidity, banks increase their claims on the Central Bank. ECB

\footnotetext{
${ }^{6}$ During downturns, households' saving rate in core countries remains relatively stable while in periphery countries households increase their savings for precautionary reasons at the beginning but after some years their saving rates start falling in order to maintain their consumption level.
} 
funding growth rate soars in the first four quarters and remains high after 10 quarters. ${ }^{7}$ This is due mainly to the need of periphery countries to meet their funding constraints. These countries more than double this kind of funding in the first year after the shock and keep depending on this source for a long period of time. Core countries, on the other hand, seem to be more resilient to the funding stress and ECB funding growth is considerably less pronounced.

The way the shock in the spread is transmitted to the real economy is shown in Figures A2, A3, and A4 in the Appendix. GDP growth decreases following the liquidity shock, reaching its trough after 5 quarters for the whole sample and core countries. After that, the negative effect starts bottoming out. Periphery countries exhibit a more permanent impact on GDP growth. There is a strong and relatively permanent decline in the growth rate of loans as well. Two years after the initial shock, loan growth continues to decelerate. This decline is much more pronounced in periphery countries than in core countries, which experience a smoother downturn and start to recover after 5 quarters.

All in all, our results show that during liquidity crises we observe that periphery countries, which have higher liquidity constraints, use ECB funding as a substitute for wholesale funding and deposits, while core countries, which are not so dependent on the Central Bank, use a wider range of funding sources. The resources provided by the ECB help to alleviate funding stress but this is not followed by a credit expansion. In fact, periphery countries suffer a larger downturn in banks' loans growth than core countries despite experiencing a similar negative impact on GDP.
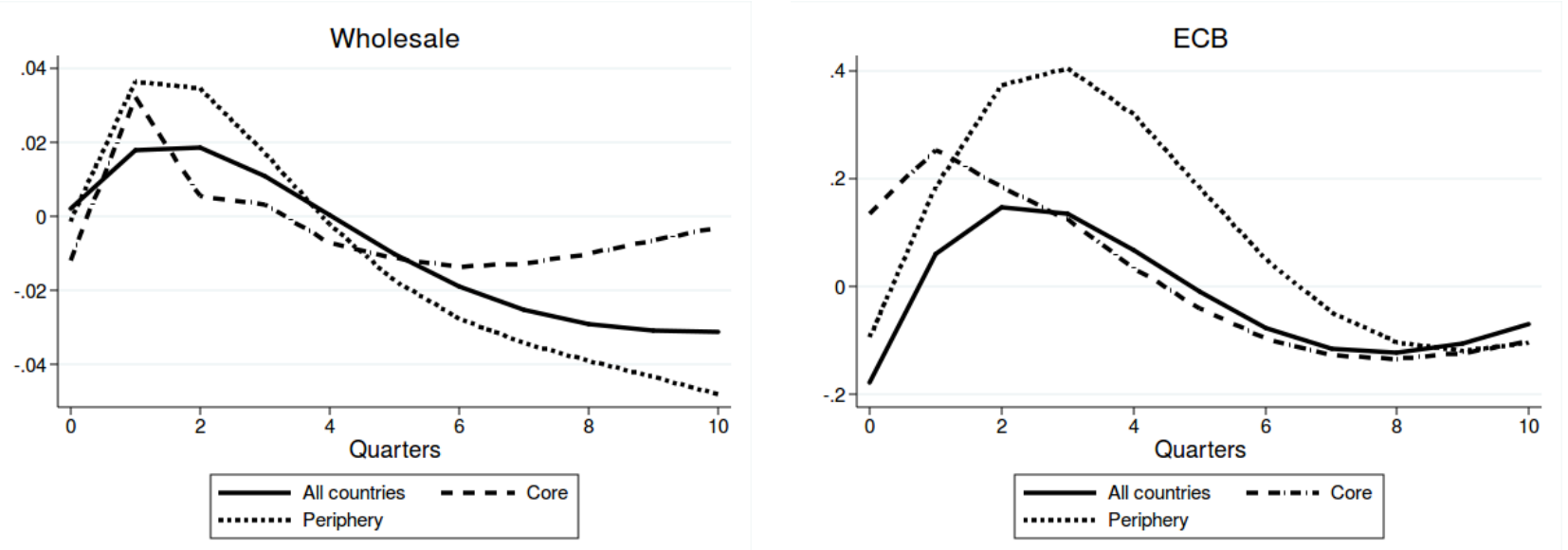

Fig. 3 Impulse response functions to a spread shock. Percentage point change from average growth rate.

Next, in Figure 3 we look at the impulse responses of wholesale and ECB funding for the three panels. The impulse response functions for all the variables, as well as the cumulative responses

\footnotetext{
${ }^{7}$ As we increase the time horizon for the responses, the standard errors of the estimated responses increase (especially for the subsamples), which explains why the cumulative response for all countries is a bit lower than for the core.
} 
for the core and periphery can be found in the Appendix. Several findings are worth highlighting: 1) Wholesale liquidity funding shocks to the spread cause banks to adjust their funding mix through initial increases in their reliance on the ECB and wholesale market funding. However, after 4 quarters, there is an increase in reliance on the ECB and a decrease in wholesale funding. 2) This shock causes a relatively persistent impact on loan activity, which eventually dries up the wholesale market. 3) There is a heterogeneous response of core and periphery countries, with the latter experiencing a greater fall in deposits and market wholesale funding (compensated by a higher reliance on ECB funding) and a sharper fall in loan and GDP growth. Regarding the differences in behavior between periphery and core, the composition of banks' funding seems to play a relevant role alongside the leverage of the country's financial system. ${ }^{8}$

Our results have important implications for financial regulation and macroprudential policy since they point towards the need to implement minimum capital requirements or similar to assure financial soundness. In fact, capital flows from periphery to core countries put into evidence the risks of the financial fragmentation given the uncompleted banking union in the Euro area. When macroeconomic conditions deteriorate, we observe capital flowing from periphery to core countries. During the crisis, this phenomenon harmed banks' balance sheets, increasing their funding costs (Al-Eyd and Berkmen (2013)) and therefore hampering monetary policy transmission through the credit channel. This phenomenon was amplified by the fact that periphery countries were more exposed to foreign investors and the relatively high degree of openness in their banking sector (Abascal et al. (2015)).

\section{Robustness}

We have addressed the impact of the liquidity channel on banks' lending and the real economy and have taken a stand, as described in section 5, in the modelling choices. In this section, we re-estimate the model to assess the robustness of the results by performing three checks. First, we expand the model to include the yield of the national treasury bond as an endogenous variable. Second, we alter our identification strategy. Third, although the SBIC criterion suggested to include one lag in the model, we re-estimate the model with two and three lags. We show that our results are robust to these changes. The estimated coefficients and impulse responses for the exercises presented in this Section are summarized in the Appendix.

\footnotetext{
${ }^{8}$ Periphery countries display higher levels of leverage in our sample, which makes them more exposed to financial system stress. In particular the average capital to assets ratio of core countries is 16.75 compared to 12.02 in periphery countries for the period studied. In addition, periphery countries are more bank-based, so banking system weaknesses have a higher impact on the rest of the economy.
} 


\subsection{Inclusion of the treasury bond as an endogenous variable}

We estimate an extended model that includes the yield of the 10-year sovereign bond in the model as an endogenous variable. The inclusion of the bond attempts to control for aggregate macroeconomic conditions that might have not been captured in the baseline specification through GDP and Spread variables. The model now becomes:

\section{$[\triangle G D P \triangle \pi \triangle \text { Loans } \triangle \text { Deposits Spread } \triangle \text { Wholesale } \triangle \text { Leverage } \triangle \text { Bond } \triangle E C B]^{\prime}$}

The cost of including a ninth variable, however, makes the estimation less precise, since we have 12 years of data and a large number of parameters to be estimated. Nevertheless, this exercise will assess if there is an omitted variable bias from not including the bond and the robustness of the responses to a liquidity shock.

Table 3 Impulse response to a spread shock: different model specifications. Baseline refers to the 8-variable specification from Section 5, Extended includes the treasury bond as an endogenous variable. The units are percentage points. Standard errors in parentheses.

\begin{tabular}{lllllll}
\hline & \multicolumn{2}{c}{ Deposits } & \multicolumn{2}{c}{ Wholesale } & \multicolumn{2}{c}{ ECB } \\
\hline Quarter & Baseline & Extended & Baseline & Extended & Baseline & Extended \\
\hline \hline 0 & 0.000 & 0.000 & 0.003 & 0.004 & -0.076 & -0.041 \\
& $(0.000)$ & $(0.000)$ & $(0.004)$ & $(0.005)$ & $(0.081)$ & $(0.078)$ \\
2 & 0.003 & 0.000 & 0.017 & 0.019 & 0.183 & 0.406 \\
& $(0.002)$ & $(0.001)$ & $(0.004)$ & $(0.004)$ & $(0.101)$ & $(0.092)$ \\
4 & 0.002 & 0.000 & -0.001 & -0.005 & 0.081 & 0.230 \\
& $(0.002)$ & $(0.002)$ & $(0.005)$ & $(0.004)$ & $(0.164)$ & $(0.137)$ \\
6 & -0.001 & 0.000 & -0.018 & -0.022 & -0.052 & -0.090 \\
& $(0.003)$ & $(0.002)$ & $(0.005)$ & $(0.004)$ & $(0.202)$ & $(0.151)$ \\
8 & -0.005 & -0.002 & -0.026 & -0.024 & -0.076 & -0.256 \\
& $(0.003)$ & $(0.002)$ & $(0.006)$ & $(0.004)$ & $(0.212)$ & $(0.145)$ \\
10 & -0.008 & -0.004 & -0.028 & -0.019 & -0.002 & -0.230 \\
& $(0.003)$ & $(0.002)$ & $(0.006)$ & $(0.004)$ & $(0.219)$ & $(0.137)$ \\
\hline
\end{tabular}

We present a comparison of the impulse responses of the baseline and the extended model in Table 3. The response of deposits and wholesale funding is remarkably similar when including the yield of the treasury bond as an additional endogenous variable, suggesting that while it is crucial to control for the heterogeneity in macroeconomic conditions across countries, GDP, inflation and leverage are already sufficient controls. The response in ECB funding demand after a liquidity funding shock in the extended model follows the baseline response closely, although the increases 
in initial claims after the shock are scaled up with respect to the baseline. Introducing the yield of the treasury bond in each country increases the precision of the panel estimates since, as we have previously shown, the substantial heterogeneity in responses between core and periphery countries makes the ECB response less precise when estimating the whole panel together. With this evidence, and while the inclusion of the treasury bond is definitely adding additional control to the estimation, given the length of our data we corroborate that the baseline model provides a good framework to study banks' responses following a shock to the spread.

\subsection{Sensitivity of results to changes in the ordering of the variables}

In section 5 we discussed the motivation for our choice for the ordering of the variables in the panel VAR model. In this section we will check the robustness of our results to changes in this ordering. In particular, we will follow de Haan and van den End (2013) and assume that wholesale variables (i.e., spread and wholesale) respond more quickly than retail items (loans and deposits). The reasoning behind this ordering takes into account the shorter maturities of wholesale instruments, which allow for quicker adjustments if needed. The alternative ordering has an effect on the initial response of variables by construction, since we now allow these variables to respond to the spread shock contemporaneously. Nevertheless, the impulse responses and the cumulative responses are comparable to the baseline. Deposits and Wholesale initially decrease faster under the alternative ordering, but the responses are comparable after 6 periods. The response of the ECB after a spread shock is qualitatively similar. The decrease of credit is quantitatively similar under both specifications.

\subsection{Sensitivity of outcomes to changes in the number of lags}

We motivated the choice of one lag in section 5 as indicated by the SBIC criterion. We also performed robustness checks for the number of lags by re-estimating the model and comparing the impulse responses of the model with two and three lags to the model with one lag.

Figure 4 shows the impulse response of GDP, Wholesale funding, ECB, and Loans to a spread shock for the whole panel. Although the sign and co-movement of the responses do not change, the models with two and three lags have a somewhat smaller response and faster recovery compared to the original model. The largest difference occurs in the recovery of GDP, especially after 4 quarters, with a larger and more persistent drop in GDP in the baseline model with one lag. The models with two and three lags respond very similarly, although the coefficients are estimated more imprecisely given the reduction in degrees of freedom (results presented in the Appendix). We interpret these results as a validation exercise for the baseline model. By incorporating more historical information, the variables do not respond as strongly as they do when only including information from the previous period in the first year after the shock, but the differences are mild. 

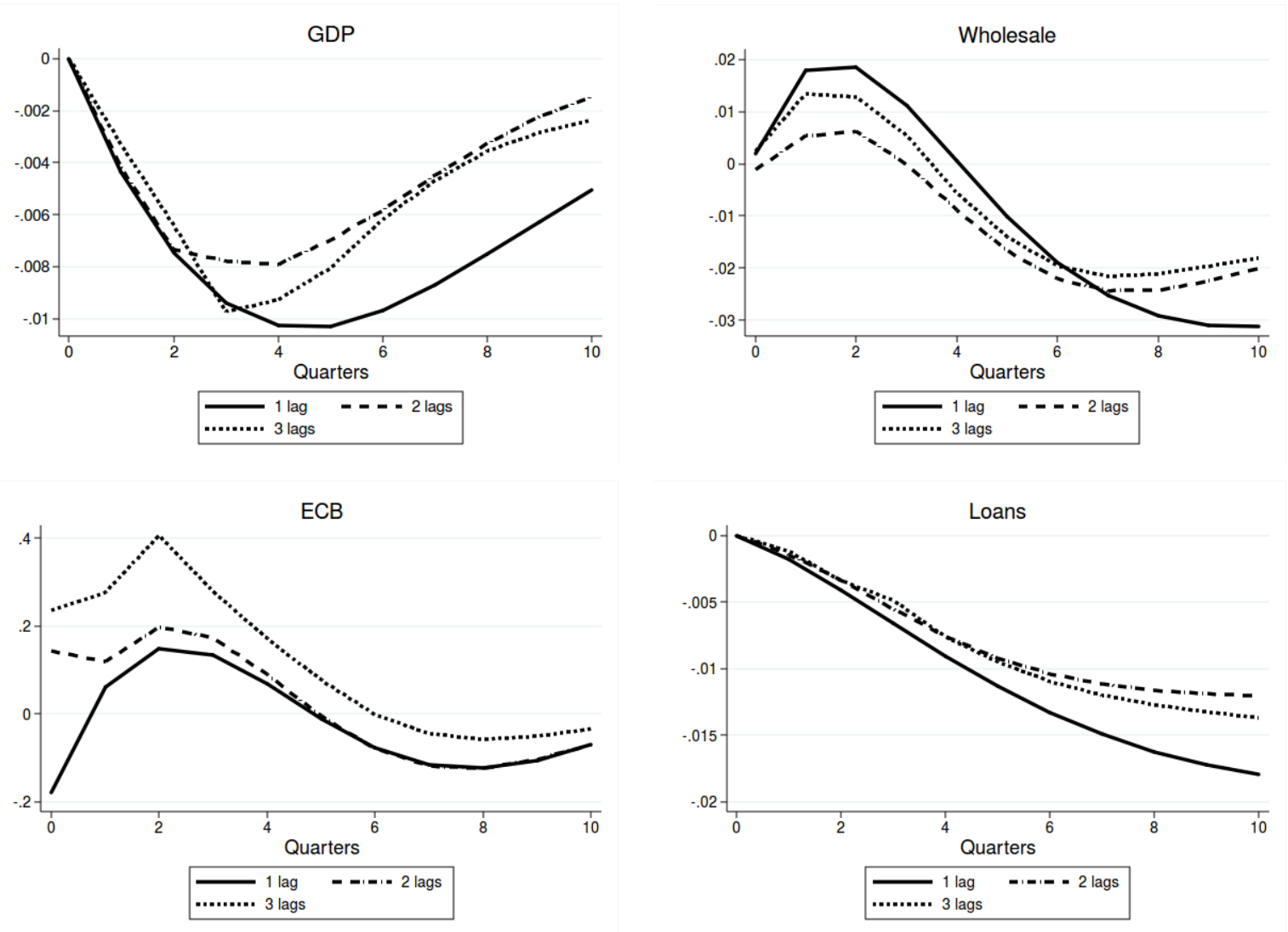

Fig. 4 Impulse responses to a spread shock: different lag specifications. The units are percentage points

\section{Conclusions}

This paper provides empirical evidence on the impact of wholesale liquidity funding shocks in the Euro area. In particular, we analyze their effects on lending to households and non-financial corporations by the banking sector as well as on economic activity with quarterly data of eight Eurozone countries over the 2003-2015 period. To do that, we model the dynamic interdependencies among the macroeconomic and financial variables in a panel Vector Autoregressive (p-VAR) setup. To assess the heterogeneity across countries, we split our sample into two groups: core and periphery countries.

A liquidity funding shock is simulated through an increase in the Euribor-OIS spread. The results derived from the analysis of the impulse response functions reveal that banks substitute, to a greater or lesser extent, wholesale funding with ECB funding. The latter proves necessary to address banks' funding shortages but it does not assure a credit expansion once funding problems fade away. In fact, the liquidity shock significantly affects both economic activity and credit growth. The impact on GDP tends to revert faster, whereas in the case of credit the effect turns out to be more persistent. 
We observe heterogeneous responses in core and periphery countries, with the latter experiencing more pronounced falls both in GDP and credit growth, and the negative effects from the shock last longer than in core countries. Additionally, periphery countries experience a greater fall in deposits and market wholesale funding (compensated by a higher reliance on ECB funding). We have performed three robustness checks: the inclusion of the sovereign bond as an endogenous variable, a change in the ordering of the variables, and a change in the lag structure. Our results are robust to the different model specifications.

All in all, the results show that funding liquidity risk is an important factor to take into account once the Central Bank starts tapering its accommodative monetary policy stance held since the beginning of the GFC. In particular, we believe that these results have important implications for financial regulation and macroprudential policy, since they point towards the need to implement minimum capital requirements or similar to assure financial soundness. 


\section{References}

Abascal M, Alonso T, Mayordomo S, Rodriguez-Moreno M (2015) Fragmentation in the european interbank market: Measures, determinants, and policy solutions. Journal of Financial Stability $16: 1-12$

Abrigo M, Love I (2016) Estimation of panel vector autoregression in stata: a package of programs. University of Hawaii Working paper

Afonso G, Kovner A, Schoar A (2011) Stressed, not frozen: The federal funds market in the financial crisis. Journal of Finance 66:1109-1139

Al-Eyd M, Berkmen P (2013) Fragmentation and monetary policy in the euro area. International Monetary Fund Working paper No 13-208

Altavilla C, Paries MD, Nicoletti G (2015) Loan supply, credit markets and the euro area financial crisis. European Central Bank Working Paper 1861

Arellano M, Bover O (1995) Another look at the instrumental variable estimation of error component models. Journal of Econometrics 68:29-51

Baglioni A (2012) Liquidity crunch in the interbank market: Is it credit or liquidity risk, or both? Journal of Financial Services Research 41 (1-2):1-18

Bassett WF, Chosak MB, Driscoll JC, Zakrajsek E (2014) Changes in bank lending standards and the macroeconomy. Journal of Monetary Economics 62:23-40

Bernanke BS, Gertler M (1995) Inside the black box: The credit channel of monetary policy transmission. The Journal of Economic Perspectives 9:27-48

Bernanke BS, Lown CS (1991) The credit crunch. Brookings Papers on Economic Activity 2:205247

Bijsterbosch M, Falagiarda M (2014) Credit supply dynamics and economic activity in euroarea countries: A time-varying parameter var analysis. ECB Working Paper 1714

BIS (2011) The transmission channels between the financial and real sectors: A critical survey of the literature. Basel Committee on Banking Supervision Working paper 18

Brunetti C, di Filippo M, Harris JH (2011) Effects of central bank intervention on the interbank market during the subprime crisis. The Review of Financial Studies 24(6):2053-2083

Brunnermeier M, Oehmke M (2013) The maturity rat race. Journal of Finance 68(2):483-521 
Brunnermeier M, Pedersen L (2009) Market liquidity and funding liquidity. Review of Financial Studies 22(6):2201-2238

Calomiris CW, Kahn CM (1991) The role of demandable debt in structuring optimal banking arrangements. American Economic Review 81(497-513)

Christiano LJ, Eichenbaum M, Evans C (1996) The effects of monetary policy shocks: Evidence from the flow of funds. The Review of Economics and Statistics 78:16-34

Christiano LJ, Eichenbaum M, Evans C (2000) Monetary policy shocks: what have we learned and to what end? Handbook of Macroeconomics

Ciccarelli M, Maddaloni A, Peydró JL (2013) Heterogeneous transmission mechanism: monetary policy and financial fragility in the eurozone. Economic Policy 28(75):459-512

Ciccarelli M, Maddaloni A, Peydró JL (2014) Trusting the bankers: A new look at the credit channel of monetary policy. Review of Economic Dynamics 18:979-1002

Darracq-Paries M, Santis RAD (2015) A non-standard monetary policy shock: The ecb's 3-year ltros and the shift in credit supply. Journal of International Money and Finance 54:1-34

Dietrich D, Vollmer U (2010) International banking and liquidity allocation: Cross-border financial services versus multinational banking. Journal of Financial Services Research 37 (1):45-69

Farhi E, Tirole J (2012) Collective moral hazard, maturity mismatch, and systemic bailouts. American Economic Review 102:60-93

Feldman RJ, Schmidt J (2001) Increased use of uninsured deposits. Federal Reserve Bank of Minneapolis-Fed Gazette

Freixas X, Holthausen C (2005) Interbank market integration under asymmetric information. Review of Financial Studies 18:459-490

Giannone D, Lenza M, Pill H, Reichlin L (2012) The ecb and the interbank market. Economic Journal 122:467-486

Gilchrist S, Zakrajsek E (2012) Credit spreads and business cycle fluctuations. American Economic Review 102:1692-1720

Goldsmith-Pinkham P, Yorulmazer T (2010) Liquidity, bank runs, and bailouts: Spillover effects during the northern rock episode. Journal of Financial Services Research 37 (2-3):83-98 
de Haan L, van den End JW (2013) Banks' responses to funding liquidity shocks: Lending adjustment, liquidity hoarding and fire sales. Journal of International Financial Markets, Institutions and Money 26:152-174

de Haan L, van den End JW, Vermeulen P (2017) Lenders on the storm of wholesale funding shocks: Saved by the central bank? Applied Economics 49(46):4679-4703

Hyun JS, Rhee BK (2011) Bank capital regulation and credit supply. Journal of Banking and Finance 35:323-330

IMF (2013) Changes in bank funding patters and financial stability risks. International Monetary Fund

Love I, Zicchino L (2006) Financial development and dynamic investment behaviour: evidence from panel var. Quarterly Review of Economics and Finance 46:190-210

Lown CS, Morgan DP (2006) The credit cycle and the business cycle: New findings using the loan officer opinion survey,. Journal of Money, Credit and Banking 38:1575-1597

van Rixtel AARJM, Gasperini G (2013) Financial crises and bank funding: Recent experience in the euro area. BIS Working Paper No 406

Rochet JC, Tirole J (1996) Controlling risk in payment systems. Journal of Money, Credit and Banking 28:832-862

Uribe M, Yue V (1996) Country spreads and emerging countries: Who drives whom? Journal of International Economics 69:3-36

Vazquez F, Federico P (2015) Bank funding structures and risk: Evidence from the global financial crisis. Journal of Banking and Finance 61:1-14 


\section{Appendix}

Table A1 Estimation results: all countries. VAR panel is estimated by GMM with $t$ statistics in parentheses. Fixed effects are removed prior to estimation (see Section 5).

\begin{tabular}{|c|c|c|c|c|c|c|c|c|}
\hline \multirow[b]{2}{*}{ Explanatory variable } & \multicolumn{8}{|c|}{ Dependent variable } \\
\hline & GDP & $\pi$ & Loans & Deposits & Spread & Wholesale & Leverage & $\mathrm{ECB}$ \\
\hline \multirow[t]{2}{*}{$\operatorname{GDP}(t-1)$} & $0.832^{* * *}$ & 0.0185 & $0.323^{* * *}$ & -0.106 & 0.0289 & $2.310^{* * *}$ & $1.434^{* * *}$ & $21.93^{* * *}$ \\
\hline & $(26.20)$ & $(1.15)$ & $(8.67)$ & $(-1.52)$ & $(0.07)$ & $(10.70)$ & $(9.91)$ & $(4.25)$ \\
\hline \multirow{2}{*}{$\pi(t-1)$} & $-0.426^{* * *}$ & $0.743^{* * *}$ & 0.0859 & $1.991^{* * *}$ & $6.044^{* * *}$ & $-1.545^{* * *}$ & $-2.470^{* * *}$ & $-124.7^{* * *}$ \\
\hline & $(-7.53)$ & $(21.35)$ & $(1.03)$ & $(16.19)$ & $(8.20)$ & $(-5.26)$ & $(-11.93)$ & $(-13.22)$ \\
\hline \multirow[t]{2}{*}{ Loans $(t-1)$} & $0.0593^{* * *}$ & 0.0104 & $0.838^{* * *}$ & $-0.167^{* * *}$ & $-0.459^{* * *}$ & -0.0391 & $0.0704^{*}$ & $17.41^{* * *}$ \\
\hline & $(5.27)$ & $(1.36)$ & $(45.82)$ & $(-6.29)$ & $(-2.91)$ & $(-0.53)$ & $(1.76)$ & $(8.27)$ \\
\hline \multirow{2}{*}{ Deposits $(t-1)$} & 0.00159 & -0.00335 & $0.221^{* * *}$ & $0.874^{* * *}$ & 0.145 & $0.598^{* * *}$ & 0.0376 & $-17.79^{* * *}$ \\
\hline & $(0.12)$ & $(-0.42)$ & $(7.53)$ & $(22.50)$ & $(0.66)$ & $(6.00)$ & $(0.70)$ & $(-5.01)$ \\
\hline \multirow[t]{2}{*}{ Spread $(t-1)$} & $-0.0211^{* * *}$ & $-0.00455^{* * *}$ & $-0.00889^{* * *}$ & $0.00962^{* *}$ & $0.872^{* * *}$ & $0.0737^{* * *}$ & 0.0132 & $0.870^{* * *}$ \\
\hline & $(-10.21)$ & $(-3.64)$ & $(-3.44)$ & $(2.15)$ & $(23.74)$ & $(5.55)$ & $(1.60)$ & $(2.76)$ \\
\hline \multirow[t]{2}{*}{ Wholesale $(t-1)$} & $-0.0136^{* * *}$ & 0.000840 & -0.000436 & $0.0267^{* * *}$ & 0.0959 & $0.683^{* * *}$ & 0.00962 & -0.181 \\
\hline & $(-4.13)$ & $(0.37)$ & $(-0.06)$ & $(2.94)$ & $(1.35)$ & $(22.87)$ & $(0.56)$ & $(-0.30)$ \\
\hline \multirow[t]{2}{*}{ Leverage $(t-1)$} & $-0.00938^{*}$ & 0.00597 & -0.0133 & 0.00158 & $-0.185^{* *}$ & -0.0499 & $0.856^{* * *}$ & 0.907 \\
\hline & $(-1.93)$ & $(1.45)$ & $(-1.24)$ & $(0.13)$ & $(-2.44)$ & $(-1.26)$ & $(29.73)$ & $(1.01)$ \\
\hline \multirow[t]{2}{*}{$\operatorname{ECB}(t-1)$} & -0.00000424 & 0.0000938 & 0.000135 & 0.000643 & $-0.00908^{* *}$ & $-0.00441^{* * *}$ & $0.00249^{*}$ & $0.617^{* * *}$ \\
\hline & $(-0.02)$ & $(0.74)$ & $(0.34)$ & $(1.13)$ & $(-1.97)$ & $(-3.13)$ & $(1.95)$ & $(10.48)$ \\
\hline$N$ & 352 & & & & & & & \\
\hline
\end{tabular}

${ }^{*} p<0.10,{ }^{* *} p<0.05,{ }^{* * *} p<0.01$ 
Table A2 Estimation results: core countries only. VAR panel is estimated by GMM with $t$ statistics in parentheses. Fixed effects are removed prior to estimation.

\begin{tabular}{|c|c|c|c|c|c|c|c|c|}
\hline \multirow[b]{2}{*}{ Explanatory variable } & \multicolumn{8}{|c|}{ Dependent variable } \\
\hline & GDP & $\pi$ & Loans & Deposits & Spread & Wholesale & Leverage & $\mathrm{ECB}$ \\
\hline \multirow{2}{*}{$\operatorname{GDP}(t-1)$} & $0.798^{* * *}$ & $0.041^{* * *}$ & $0.176^{* * *}$ & -0.002 & -0.141 & $2.744^{* * *}$ & $1.048^{* * *}$ & $5.118^{* *}$ \\
\hline & $(35.35)$ & $(3.47)$ & $(4.58)$ & $(-0.09)$ & $(-0.40)$ & $(13.46)$ & $(8.37)$ & $(2.10)$ \\
\hline \multirow[t]{2}{*}{$\pi(t-1)$} & $-0.664^{* * *}$ & $0.697^{* * *}$ & $0.631^{* * *}$ & 0.109 & $-6.626^{* * *}$ & $-5.252^{* * *}$ & $-2.258^{* * *}$ & $-99.49^{* * *}$ \\
\hline & $(-8.51)$ & $(13.79)$ & $(3.99)$ & $(0.86)$ & $(-4.47)$ & $(-6.48)$ & $(-4.40)$ & $(-10.20)$ \\
\hline \multirow[t]{2}{*}{ Loans $(t-1)$} & $0.075^{* * *}$ & $-0.020^{* * *}$ & $0.565^{* * *}$ & $-0.038^{* *}$ & $-1.346^{* * *}$ & $2.061^{* * *}$ & $-0.120^{*}$ & $15.48^{* * *}$ \\
\hline & $(5.65)$ & $(-3.35)$ & $(24.59)$ & $(-2.13)$ & $(-5.46)$ & $(14.13)$ & $(-1.76)$ & $(11.35)$ \\
\hline \multirow[t]{2}{*}{ Deposits $(t-1)$} & $0.282^{* * *}$ & 0.000 & -0.081 & $0.830^{* * *}$ & $-1.123^{* * *}$ & $1.964^{* * *}$ & $-1.225^{* * *}$ & $-10.71^{* * *}$ \\
\hline & $(11.66)$ & $(0.03)$ & $(-1.52)$ & $(29.83)$ & $(-3.46)$ & $(5.50)$ & $(-9.34)$ & $(-4.46)$ \\
\hline \multirow{2}{*}{ Spread $(t-1)$} & $-0.010^{* * *}$ & $-0.003^{* * *}$ & $-0.028^{* * *}$ & 0.003 & $0.679^{* * *}$ & $0.153^{* * *}$ & 0.002 & $0.746^{* * *}$ \\
\hline & $(-4.80)$ & $(-4.92)$ & $(-9.23)$ & $(1.64)$ & $(27.32)$ & $(8.20)$ & $(0.28)$ & $(4.63)$ \\
\hline \multirow[t]{2}{*}{ Wholesale $(t-1)$} & $-0.047^{* * *}$ & $0.011^{* * *}$ & $0.085^{* * *}$ & 0.004 & $1.206^{* * *}$ & 0.069 & $0.195^{* * *}$ & -0.503 \\
\hline & $(-10.93)$ & $(5.60)$ & $(9.25)$ & $(1.07)$ & $(12.16)$ & $(1.40)$ & $(12.63)$ & $(-1.05)$ \\
\hline \multirow[t]{2}{*}{ Leverage $(t-1)$} & -0.002 & $-0.005^{* *}$ & -0.018 & $0.014^{* *}$ & $-0.865^{* * *}$ & $0.383^{* * *}$ & $0.745^{* * *}$ & $1.209^{* * *}$ \\
\hline & $(-0.31)$ & $(-2.28)$ & $(-1.62)$ & $(2.33)$ & $(-8.58)$ & $(4.71)$ & $(25.51)$ & $(3.07)$ \\
\hline \multirow[t]{2}{*}{$\operatorname{ECB}(t-1)$} & $0.000^{* *}$ & $0.001^{* * *}$ & $-0.003^{* * *}$ & 0.000 & $-0.020^{* * *}$ & $-0.008^{* *}$ & 0.001 & $0.649^{* * *}$ \\
\hline & $(2.09)$ & $(6.50)$ & $(-5.55)$ & $(0.72)$ & $(-4.50)$ & $(-2.06)$ & $(1.60)$ & $(13.69)$ \\
\hline$N$ & 176 & & & & & & & \\
\hline
\end{tabular}


Table A3 Estimation results: periphery countries only. VAR panel is estimated by GMM with $t$ statistics in parentheses. Fixed effects are removed prior to estimation.

\begin{tabular}{|c|c|c|c|c|c|c|c|c|}
\hline \multirow[b]{2}{*}{ Explanatory variable } & \multicolumn{8}{|c|}{ Dependent variable } \\
\hline & GDP & $\pi$ & Loans & Deposits & Spread & Wholesale & Leverage & ECB \\
\hline \multirow[t]{2}{*}{$\operatorname{GDP}(t-1)$} & $0.751^{* * *}$ & $0.0373^{*}$ & -0.00324 & $-0.324^{* * *}$ & $-1.262^{* * *}$ & $1.698^{* * *}$ & $1.151^{* * *}$ & $53.57^{* * *}$ \\
\hline & $(30.07)$ & $(1.76)$ & $(-0.08)$ & $(-5.38)$ & $(-4.77)$ & $(8.32)$ & $(12.56)$ & $(10.33)$ \\
\hline \multirow[t]{2}{*}{$\pi(t-1)$} & $0.599^{* * *}$ & $0.804^{* * *}$ & $1.126^{* * *}$ & $1.354^{* * *}$ & $-4.781^{* * *}$ & $4.265^{* * *}$ & $-0.791^{* * *}$ & $-145.4^{* * *}$ \\
\hline & $(15.55)$ & $(22.52)$ & $(15.51)$ & $(14.22)$ & $(-14.43)$ & $(11.55)$ & $(-6.25)$ & $(-18.72)$ \\
\hline \multirow[t]{2}{*}{ Loans $(t-1)$} & $-0.0648^{* * *}$ & $-0.0208^{* * *}$ & $0.858^{* * *}$ & $-0.107^{* * *}$ & $0.646^{* * *}$ & $-0.601^{* * *}$ & 0.0154 & $14.89^{* * *}$ \\
\hline & $(-5.58)$ & $(-3.33)$ & $(58.13)$ & $(-5.25)$ & $(6.32)$ & $(-8.22)$ & $(0.69)$ & $(8.80)$ \\
\hline \multirow{2}{*}{ Deposits $(t-1)$} & $0.0334^{* * *}$ & $0.0338^{* * *}$ & $0.0632^{* * *}$ & $0.936^{* * *}$ & 0.230 & $0.653^{* * *}$ & -0.0115 & $-18.22^{* * *}$ \\
\hline & $(3.10)$ & $(5.17)$ & $(3.55)$ & $(27.86)$ & $(1.43)$ & $(6.02)$ & $(-0.40)$ & $(-8.33)$ \\
\hline \multirow[t]{2}{*}{ Spread $(t-1)$} & $-0.0190^{* * *}$ & $-0.00990^{* * *}$ & $-0.00648^{* *}$ & $-0.00940^{* * *}$ & $0.640^{* * *}$ & $0.177^{* * *}$ & $0.0224^{* * *}$ & $1.475^{* * *}$ \\
\hline & $(-8.84)$ & $(-6.65)$ & $(-2.17)$ & $(-2.77)$ & $(22.56)$ & $(9.95)$ & $(3.34)$ & $(5.95)$ \\
\hline \multirow[t]{2}{*}{ Wholesale $(t-1)$} & $0.0175^{* *}$ & $0.00728^{* *}$ & $0.0294^{* * *}$ & $0.0269^{* * *}$ & $-0.362^{* * *}$ & $0.804^{* * *}$ & -0.0167 & 0.426 \\
\hline & $(2.55)$ & $(2.46)$ & $(3.84)$ & $(3.67)$ & $(-5.50)$ & $(23.93)$ & $(-1.46)$ & $(0.69)$ \\
\hline \multirow[t]{2}{*}{ Leverage $(t-1)$} & $-0.0169^{* * *}$ & 0.00192 & $-0.0531^{* * *}$ & $0.0485^{* * *}$ & $0.319^{* * *}$ & $-0.0973^{*}$ & $0.826^{* * *}$ & -1.408 \\
\hline & $(-3.13)$ & $(0.34)$ & $(-5.38)$ & $(4.16)$ & $(4.18)$ & $(-1.81)$ & $(40.23)$ & $(-1.63)$ \\
\hline \multirow[t]{2}{*}{$\mathrm{ECB}(t-1)$} & $-0.000247^{*}$ & $0.000285^{*}$ & 0.000492 & $0.00165^{* * *}$ & $0.0105^{* * *}$ & $-0.00761^{* * *}$ & 0.000671 & $0.679^{* * *}$ \\
\hline & $(-1.71)$ & $(1.90)$ & $(1.36)$ & $(3.74)$ & $(3.27)$ & $(-4.91)$ & $(0.85)$ & $(15.92)$ \\
\hline$N$ & 176 & & & & & & & \\
\hline
\end{tabular}

${ }^{*} p<0.10,{ }^{* *} p<0.05,{ }^{* * *} p<0.01$ 

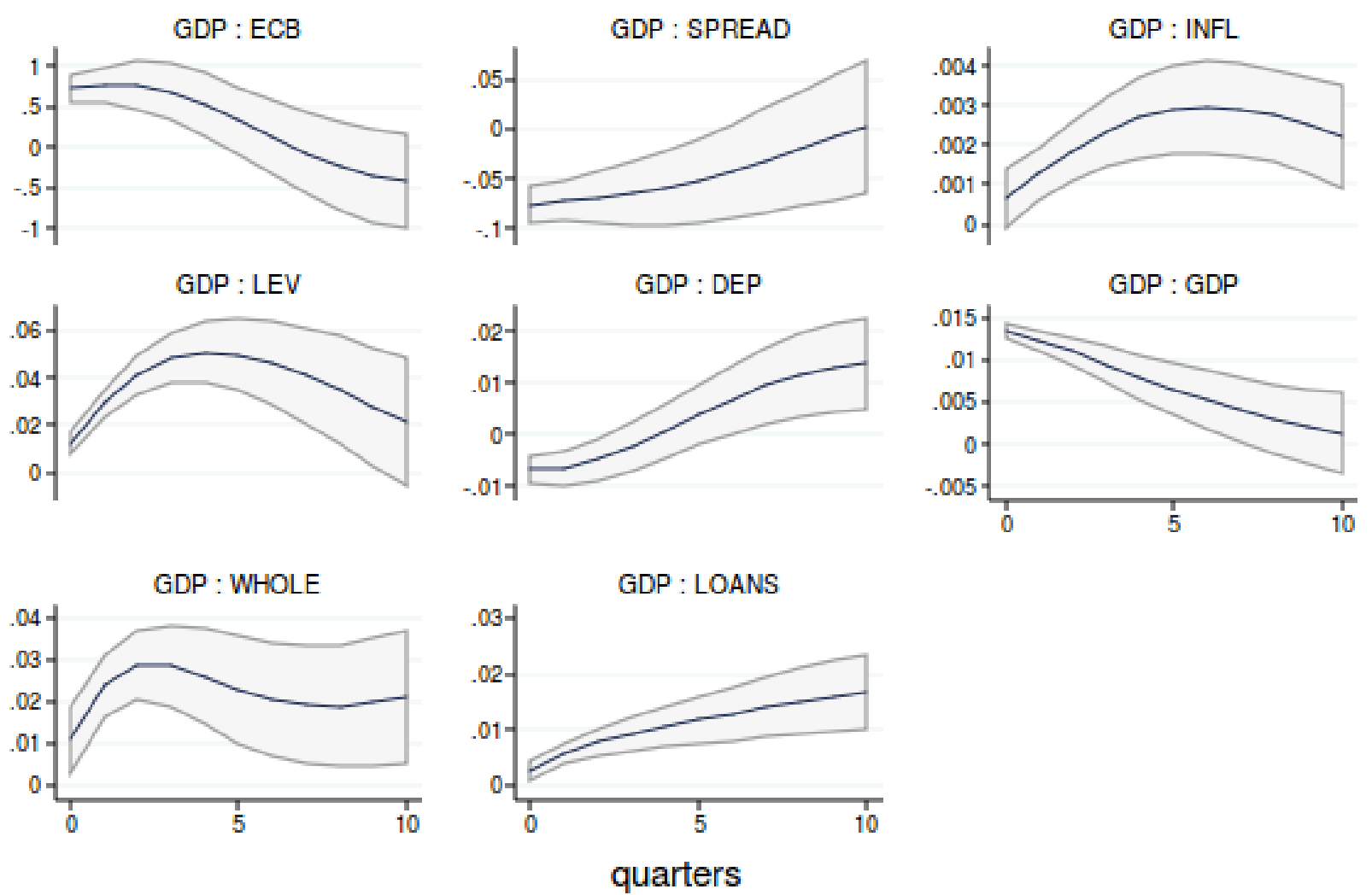

$90 \% \mathrm{Cl}$

Orthogonalized IRF

Fig. A1 Impulse response functions: GDP shock panel 


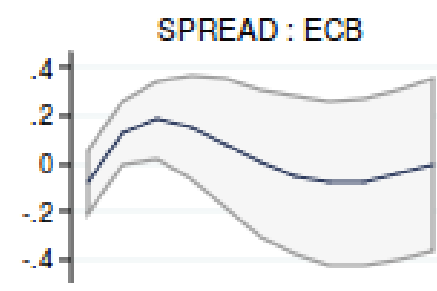

SPREAD : LEV

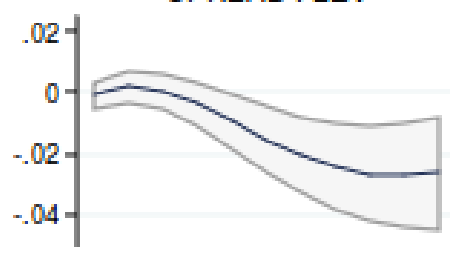

SPREAD : WHOLE
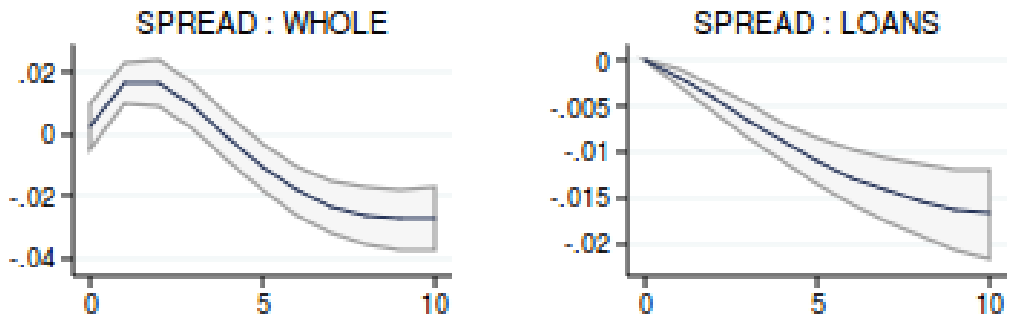

quarters

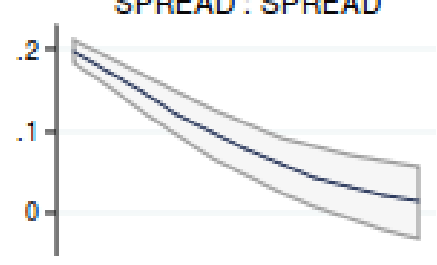

SPREAD : DEP
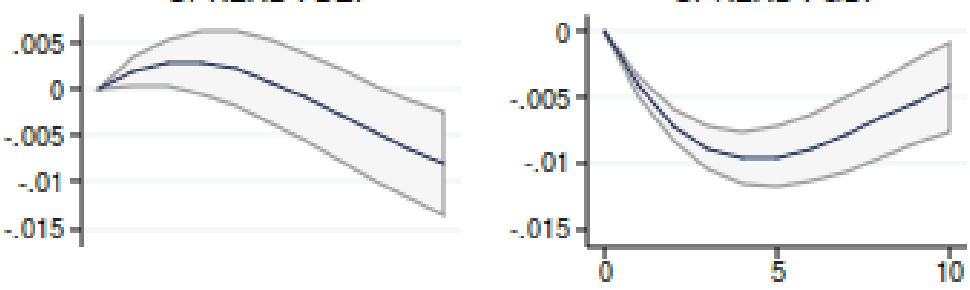

$90 \% \mathrm{Cl}$

Orthogonalized IRF

Fig. A2 Impulse response functions: Spread shock panel 

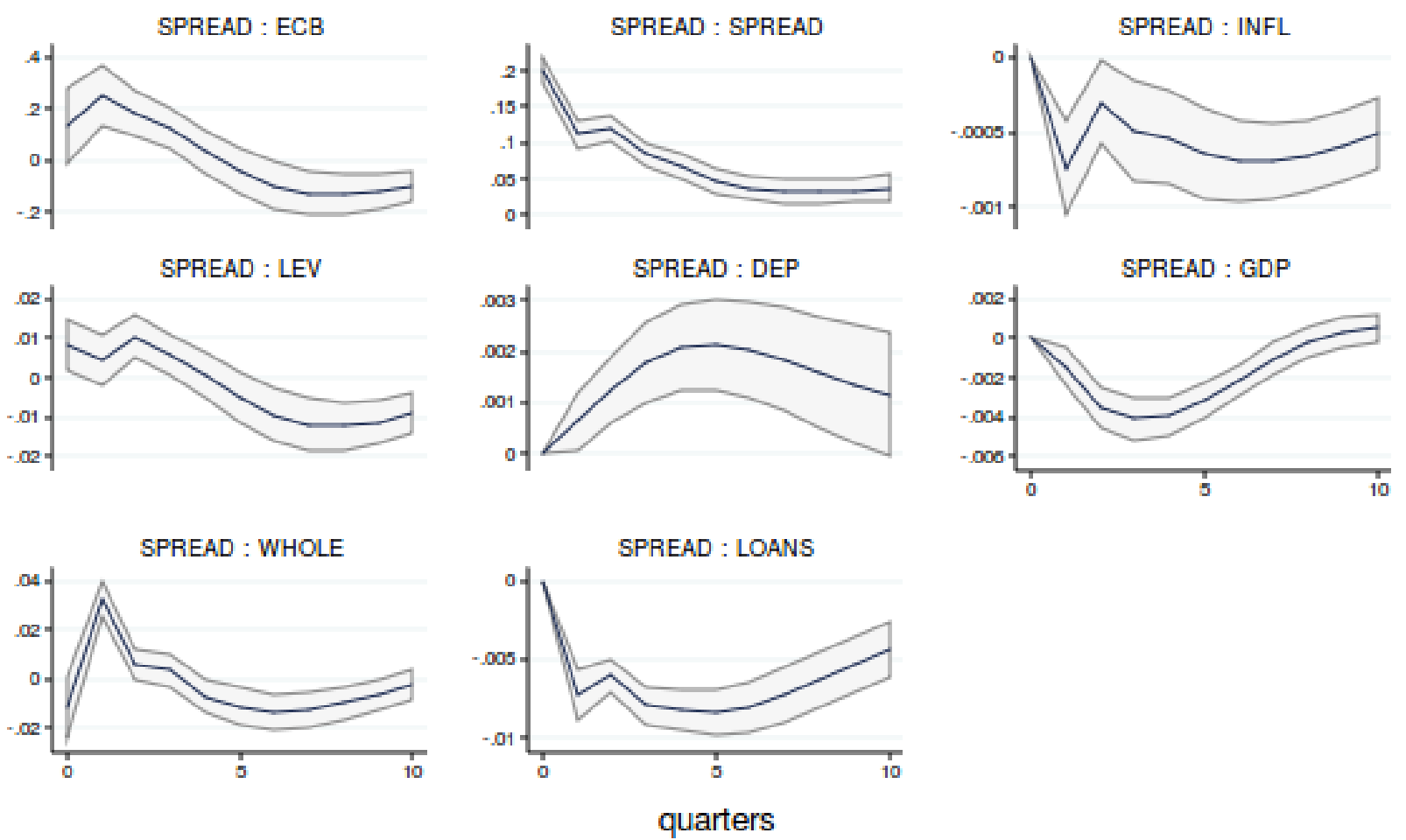

$90 \% \mathrm{Cl}$

Orthogonalized IRF

Fig. A3 Impulse response functions: Spread shock core countries 

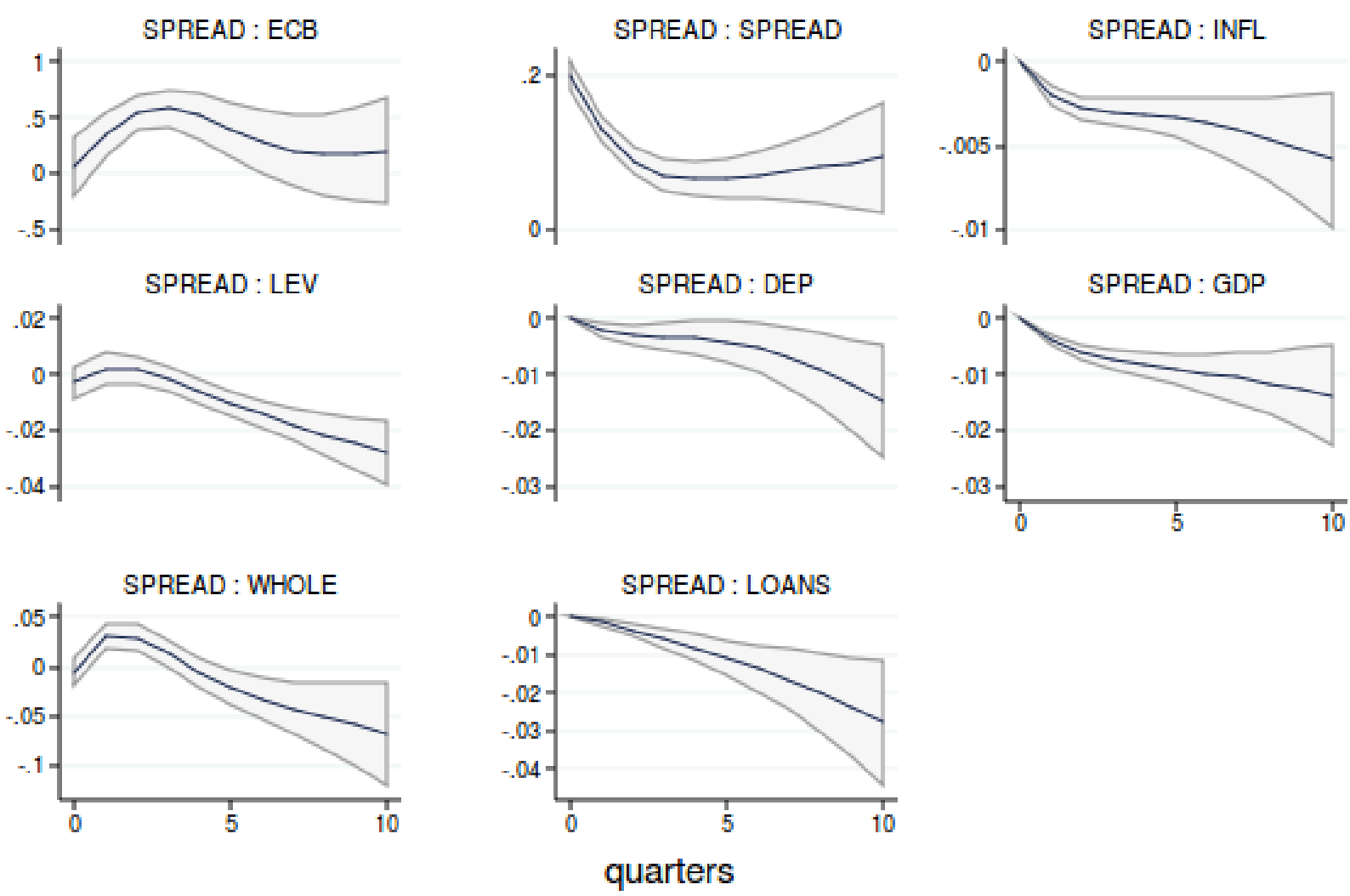

$90 \% \mathrm{Cl}$

Orthogonalized IRF

Fig. A4 Impulse response functions: Spread shock periphery countries 
Table A4 Cumulative impulse response functions of core countries to a temporary shock of 20 basis points to the spread level

\begin{tabular}{llllll}
\hline Quarter & \multicolumn{1}{c}{2} & \multicolumn{1}{c}{4} & \multicolumn{1}{c}{6} & \multicolumn{1}{c}{8} & \multicolumn{1}{c}{10} \\
\hline Deposit & 0.002 & 0.006 & 0.010 & 0.013 & 0.016 \\
& $(0.001)$ & $(0.002)$ & $(0.003)$ & $(0.004)$ & $(0.005)$ \\
ECB & 0.574 & 0.734 & 0.599 & 0.338 & 0.114 \\
& $(0.194)$ & $(0.234)$ & $(0.264)$ & $(0.303)$ & $(0.344)$ \\
GDP & -0.005 & -0.013 & -0.018 & -0.019 & -0.019 \\
& $(0.001)$ & $(0.002)$ & $(0.003)$ & $(0.004)$ & $(0.004)$ \\
Inflation & -0.001 & -0.002 & -0.003 & -0.005 & -0.006 \\
& $(0.000)$ & $(0.001)$ & $(0.001)$ & $(0.001)$ & $(0.001)$ \\
Leverage & 0.024 & 0.030 & 0.015 & -0.009 & -0.029 \\
& $(0.011)$ & $(0.015)$ & $(0.021)$ & $(0.026)$ & $(0.031)$ \\
Loans & -0.013 & -0.029 & -0.046 & -0.059 & -0.069 \\
& $(0.001)$ & $(0.003)$ & $(0.004)$ & $(0.005)$ & $(0.007)$ \\
Wholesale & 0.026 & 0.022 & -0.003 & -0.025 & -0.034 \\
& $(0.012)$ & $(0.016)$ & $(0.022)$ & $(0.028)$ & $(0.033)$ \\
\hline
\end{tabular}

Table A5 Cumulative impulse response functions of periphery countries to a temporary shock of 20 basis points to the spread level

\begin{tabular}{llllll}
\hline Quarter & \multicolumn{1}{c}{2} & \multicolumn{1}{c}{4} & \multicolumn{1}{c}{6} & \multicolumn{1}{c}{8} & \multicolumn{1}{c}{10} \\
\hline Deposit & -0.005 & -0.012 & -0.021 & -0.037 & -0.064 \\
& $(0.002)$ & $(0.005)$ & $(0.010)$ & $(0.017)$ & $(0.028)$ \\
ECB & 0.954 & 2.055 & 2.741 & 3.108 & 3.479 \\
& $(0.348)$ & $(0.471)$ & $(0.676)$ & $(1.014)$ & $(1.503)$ \\
GDP & -0.010 & -0.026 & -0.045 & -0.067 & -0.093 \\
& $(0.001)$ & $(0.003)$ & $(0.007)$ & $(0.013)$ & $(0.023)$ \\
Inflation & -0.005 & -0.011 & -0.018 & -0.027 & -0.038 \\
& $(0.001)$ & $(0.002)$ & $(0.003)$ & $(0.006)$ & $(0.010)$ \\
Leverage & 0.001 & -0.007 & -0.032 & -0.072 & -0.125 \\
& $(0.009)$ & $(0.014)$ & $(0.018)$ & $(0.023)$ & $(0.033)$ \\
Loans & -0.005 & -0.018 & -0.042 & -0.078 & -0.129 \\
& $(0.002)$ & $(0.005)$ & $(0.012)$ & $(0.023)$ & $(0.040)$ \\
Wholesale & 0.056 & 0.064 & 0.010 & -0.083 & -0.211 \\
& $(0.023)$ & $(0.037)$ & $(0.058)$ & $(0.092)$ & $(0.147)$ \\
\hline
\end{tabular}


Table A6 Estimation results: Bond included as endogenous variable. VAR panel is estimated by GMM with $t$ statistics in parentheses. Fixed effects are removed prior to estimation (see Section 5 of the paper)

\begin{tabular}{|c|c|c|c|c|c|c|c|c|c|}
\hline \multirow[b]{2}{*}{ Expl. variable } & \multicolumn{9}{|c|}{ Dependent variable } \\
\hline & GDP & $\pi$ & Loans & Deposits & Spread & Wholesale & Leverage & Bond & ECB \\
\hline \multirow[t]{2}{*}{$\operatorname{GDP}(t-1)$} & $0.852^{* * *}$ & $0.0330^{* *}$ & $0.415^{* * *}$ & $-0.172^{* * *}$ & $-0.660^{*}$ & $2.568^{* * *}$ & $1.630^{* * *}$ & $0.795^{* * *}$ & $24.08^{* * *}$ \\
\hline & $(30.38)$ & $(2.20)$ & $(10.57)$ & $(-2.84)$ & $(-1.75)$ & $(13.59)$ & $(13.51)$ & $(2.63)$ & $(5.85)$ \\
\hline \multirow[t]{2}{*}{$\pi(t-1)$} & $-0.540^{* * *}$ & $0.718^{* * *}$ & $-0.300^{* * *}$ & $1.927^{* * *}$ & $8.145^{* * *}$ & $-1.433^{* * *}$ & $-2.222^{* * *}$ & $-4.666^{* * *}$ & $-107.3^{* * *}$ \\
\hline & $(-10.83)$ & $(24.85)$ & $(-3.51)$ & $(18.72)$ & $(10.97)$ & $(-5.31)$ & $(-13.02)$ & $(-7.68)$ & $(-15.53)$ \\
\hline \multirow[t]{2}{*}{ Loans $(t-1)$} & $0.0747^{* * *}$ & 0.00733 & $0.864^{* * *}$ & $-0.174^{* * *}$ & $-0.827^{* * *}$ & $-0.140^{* *}$ & 0.0391 & $0.319^{* * *}$ & $16.55^{* * *}$ \\
\hline & $(7.41)$ & $(1.19)$ & $(51.79)$ & $(-8.44)$ & $(-5.14)$ & $(-2.09)$ & $(1.14)$ & $(2.65)$ & $(9.86)$ \\
\hline \multirow[t]{2}{*}{ Deposits $(t-1)$} & 0.00384 & 0.00302 & $0.267^{* * *}$ & $0.875^{* * *}$ & -0.0269 & $0.747^{* * *}$ & $0.103^{* *}$ & $0.762^{* * *}$ & $-20.90^{* * *}$ \\
\hline & $(0.30)$ & $(0.43)$ & $(10.19)$ & $(26.22)$ & $(-0.12)$ & $(8.08)$ & $(2.25)$ & $(4.31)$ & $(-7.44)$ \\
\hline \multirow[t]{2}{*}{ Spread $(t-1)$} & $-0.0194^{* * *}$ & $-0.00378^{* * *}$ & $-0.00558^{*}$ & -0.000465 & $0.779^{* * *}$ & $0.0968^{* * *}$ & $0.0451^{* * *}$ & $-0.0493^{* *}$ & $1.538^{* * *}$ \\
\hline & $(-9.33)$ & $(-3.73)$ & $(-1.96)$ & $(-0.12)$ & $(25.55)$ & $(7.27)$ & $(4.99)$ & $(-2.18)$ & $(5.49)$ \\
\hline \multirow[t]{2}{*}{ Wholesale $(t-1)$} & $-0.0137^{* * *}$ & 0.00139 & -0.00807 & $0.0242^{* * *}$ & $0.193^{* * *}$ & $0.682^{* * *}$ & 0.0107 & $-0.156^{* * *}$ & 0.551 \\
\hline & $(-4.48)$ & $(0.73)$ & $(-1.22)$ & $(3.32)$ & $(2.90)$ & $(24.63)$ & $(0.68)$ & $(-2.76)$ & $(1.12)$ \\
\hline \multirow[t]{2}{*}{ Leverage $(t-1)$} & $-0.00914^{* *}$ & 0.00482 & $-0.0201^{* *}$ & $0.0186^{*}$ & -0.0322 & $-0.0626^{*}$ & $0.815^{* * *}$ & 0.0720 & 0.114 \\
\hline & $(-2.14)$ & $(1.45)$ & $(-1.99)$ & $(1.86)$ & $(-0.42)$ & $(-1.69)$ & $(29.26)$ & $(0.87)$ & $(0.17)$ \\
\hline \multirow[t]{2}{*}{ Bond $(t-1)$} & $-0.00512^{* * *}$ & $-0.00162^{*}$ & $-0.00613^{* *}$ & $0.0120^{* * *}$ & $0.227^{* * *}$ & $-0.0231^{* *}$ & $-0.0463^{* * *}$ & $0.864^{* * *}$ & $-0.740^{* * *}$ \\
\hline & $(-3.28)$ & $(-1.88)$ & $(-2.18)$ & $(3.37)$ & $(9.66)$ & $(-2.27)$ & $(-5.28)$ & $(28.74)$ & $(-3.53)$ \\
\hline \multirow[t]{2}{*}{$\operatorname{ECB}(t-1)$} & 0.0000782 & 0.000147 & 0.000366 & 0.000649 & $-0.00964^{* *}$ & $-0.00556^{* * *}$ & 0.00129 & -0.00136 & $0.620^{* * *}$ \\
\hline & $(0.39)$ & $(1.24)$ & $(1.07)$ & $(1.39)$ & $(-2.56)$ & $(-4.24)$ & $(1.13)$ & $(-0.46)$ & $(12.13)$ \\
\hline$N$ & \multicolumn{9}{|l|}{352} \\
\hline
\end{tabular}


Table A7 Estimation results: two lags. VAR panel is estimated by GMM with $t$ statistics in parentheses. Fixed effects are removed prior to estimation (see Section 5)

\begin{tabular}{|c|c|c|c|c|c|c|c|c|}
\hline \multirow[b]{2}{*}{ Explanatory variable } & \multicolumn{8}{|c|}{ Dependent variable } \\
\hline & GDP & $\pi$ & Loans & Deposits & Spread & Wholesale & Leverage & $\mathrm{ECB}$ \\
\hline \multirow[t]{2}{*}{$\operatorname{GDP}(t-1)$} & $0.647^{* * *}$ & -0.0605 & $0.165^{* *}$ & -0.0541 & 1.122 & $1.385^{* * *}$ & $-0.714^{* * *}$ & 6.419 \\
\hline & $(7.57)$ & $(-1.06)$ & $(1.97)$ & $(-0.71)$ & $(1.30)$ & $(2.89)$ & $(-2.87)$ & $(0.79)$ \\
\hline \multirow[t]{2}{*}{$\operatorname{GDP}(t-2)$} & 0.00201 & 0.0634 & -0.00270 & 0.0543 & 0.255 & $0.632^{*}$ & $0.880^{* * *}$ & $9.518^{*}$ \\
\hline & $(0.03)$ & $(1.49)$ & $(-0.04)$ & $(0.99)$ & $(0.41)$ & $(1.84)$ & $(4.38)$ & $(1.77)$ \\
\hline \multirow[t]{2}{*}{$\pi(t-1)$} & 0.167 & $0.581^{* * *}$ & 0.160 & $0.528^{* * *}$ & $-1.745^{* *}$ & $-2.141^{* * *}$ & $-1.059^{* *}$ & 3.686 \\
\hline & $(1.60)$ & $(7.03)$ & $(1.50)$ & $(4.55)$ & $(-2.00)$ & $(-5.15)$ & $(-2.53)$ & $(0.42)$ \\
\hline \multirow[t]{2}{*}{$\pi(t-2)$} & $-0.227^{*}$ & $0.285^{* * *}$ & $0.323^{* * *}$ & -0.0876 & 1.292 & $2.309^{* * *}$ & $1.007^{* *}$ & -5.176 \\
\hline & $(-1.72)$ & $(4.09)$ & $(2.67)$ & $(-0.78)$ & $(1.32)$ & $(4.74)$ & $(2.19)$ & $(-0.60)$ \\
\hline \multirow[t]{2}{*}{ Loans $(t-1)$} & $0.166^{* * *}$ & 0.0419 & $0.885^{* * *}$ & $-0.138^{* * *}$ & $-1.092^{* *}$ & -0.326 & -0.234 & $10.72^{*}$ \\
\hline & $(3.69)$ & $(1.34)$ & $(13.81)$ & $(-2.80)$ & $(-2.44)$ & $(-1.18)$ & $(-1.57)$ & $(1.82)$ \\
\hline \multirow[t]{2}{*}{ Loans $(t-2)$} & $-0.117^{* * *}$ & $-0.0613^{* *}$ & -0.0287 & $0.156^{* * *}$ & $0.887^{* *}$ & 0.0399 & 0.190 & $-11.28^{* *}$ \\
\hline & $(-3.06)$ & $(-2.30)$ & $(-0.53)$ & $(3.84)$ & $(2.17)$ & $(0.16)$ & $(1.44)$ & $(-2.24)$ \\
\hline \multirow[t]{2}{*}{ Deposits $(t-1)$} & 0.00812 & -0.0255 & $0.0991^{*}$ & $1.029^{* * *}$ & 0.616 & 0.0732 & 0.0867 & -5.082 \\
\hline & $(0.22)$ & $(-1.47)$ & $(1.94)$ & (13.27) & $(1.32)$ & $(0.35)$ & $(0.85)$ & $(-0.71)$ \\
\hline \multirow[t]{2}{*}{ Deposits $(t-2)$} & -0.0423 & 0.0273 & -0.00850 & $-0.241^{* * *}$ & -0.111 & $0.516^{* *}$ & 0.00636 & 3.320 \\
\hline & $(-0.99)$ & $(1.57)$ & $(-0.18)$ & $(-3.29)$ & $(-0.26)$ & $(2.13)$ & $(0.05)$ & $(0.42)$ \\
\hline \multirow[t]{2}{*}{ Spread $(t-1)$} & $-0.0214^{* * *}$ & $-0.00514^{* *}$ & -0.00692 & $0.0112^{* *}$ & $0.715^{* * *}$ & $0.0461^{* *}$ & $-0.0265^{* *}$ & 0.180 \\
\hline & $(-5.22)$ & $(-2.23)$ & $(-1.51)$ & $(2.27)$ & $(13.29)$ & $(1.96)$ & $(-2.25)$ & $(0.40)$ \\
\hline \multirow[t]{2}{*}{ Spread $(t-2)$} & -0.00135 & -0.000824 & -0.00323 & $-0.0155^{* * *}$ & 0.0439 & 0.00648 & -0.0138 & $1.072^{*}$ \\
\hline & $(-0.34)$ & $(-0.35)$ & $(-0.62)$ & $(-2.90)$ & $(0.55)$ & $(0.21)$ & $(-0.93)$ & $(1.89)$ \\
\hline \multirow[t]{2}{*}{ Wholesale $(t-1)$} & -0.00587 & $-0.00887^{*}$ & -0.00720 & -0.00772 & $0.604^{* * *}$ & $0.750^{* * *}$ & 0.0438 & 0.820 \\
\hline & $(-0.76)$ & $(-1.92)$ & $(-0.46)$ & $(-0.84)$ & $(3.96)$ & $(11.23)$ & $(1.33)$ & $(0.85)$ \\
\hline \multirow[t]{2}{*}{ Wholesale $(t-2)$} & -0.00329 & $0.0158^{* * *}$ & 0.0176 & $0.0220^{*}$ & $-0.495^{* * *}$ & 0.0158 & -0.0118 & -0.255 \\
\hline & $(-0.51)$ & $(3.63)$ & $(1.14)$ & $(1.91)$ & $(-4.70)$ & $(0.31)$ & $(-0.34)$ & $(-0.28)$ \\
\hline \multirow[t]{2}{*}{ Leverage $(t-1)$} & 0.00554 & 0.00714 & $-0.0388^{*}$ & 0.0118 & $-0.311^{*}$ & -0.133 & $1.253^{* * *}$ & 1.292 \\
\hline & $(0.53)$ & $(0.77)$ & $(-1.76)$ & $(0.65)$ & $(-1.78)$ & $(-1.31)$ & $(23.79)$ & $(0.83)$ \\
\hline \multirow[t]{2}{*}{ Leverage $(t-2)$} & -0.0138 & 0.00283 & $0.0431^{*}$ & -0.00974 & 0.128 & 0.0387 & $-0.454^{* * *}$ & $-2.770^{*}$ \\
\hline & $(-1.28)$ & $(0.35)$ & $(1.87)$ & $(-0.54)$ & $(0.78)$ & $(0.40)$ & $(-7.80)$ & $(-1.82)$ \\
\hline \multirow[t]{2}{*}{$\operatorname{ECB}(t-1)$} & 0.000192 & 0.0000914 & 0.000119 & 0.000419 & -0.00154 & -0.00313 & $0.00348^{*}$ & $0.847^{* * *}$ \\
\hline & $(0.45)$ & $(0.41)$ & $(0.18)$ & $(0.47)$ & $(-0.19)$ & $(-1.24)$ & $(1.92)$ & $(5.71)$ \\
\hline \multirow[t]{2}{*}{$\operatorname{ECB}(t-2)$} & -0.000593 & -0.000151 & $-0.00131^{*}$ & 0.000637 & 0.00678 & -0.00381 & $-0.00329^{* *}$ & -0.190 \\
\hline & $(-1.49)$ & $(-0.77)$ & $(-1.85)$ & $(1.03)$ & $(0.61)$ & $(-1.35)$ & $(-2.00)$ & $(-1.52)$ \\
\hline$N$ & 352 & & & & & & & \\
\hline
\end{tabular}

${ }^{*} p<0.10,{ }^{* *} p<0.05,{ }^{* * *} p<0.01$ 
Table A8 Estimation results: three lags. VAR panel is estimated by GMM with $t$ statistics in parentheses. Fixed effects are removed prior to estimation (see Section 5)

\begin{tabular}{|c|c|c|c|c|c|c|c|c|}
\hline \multirow[b]{2}{*}{ Explanatory variable } & \multicolumn{8}{|c|}{ Dependent variable } \\
\hline & GDP & $\pi$ & Loans & Deposits & Spread & Wholesale & Leverage & $\mathrm{ECB}$ \\
\hline \multirow{2}{*}{$\operatorname{GDP}(t-1)$} & $0.604^{* * *}$ & 0.0136 & $0.252^{*}$ & -0.0742 & $1.859^{*}$ & 0.884 & -0.543 & -0.475 \\
\hline & $(5.72)$ & $(0.15)$ & $(1.71)$ & $(-0.54)$ & $(1.67)$ & $(1.40)$ & $(-1.26)$ & $(-0.09)$ \\
\hline \multirow[t]{2}{*}{$\operatorname{GDP}(t-2)$} & $0.178^{*}$ & 0.0162 & 0.0899 & $0.233^{* *}$ & 0.993 & 0.658 & -0.0386 & -4.392 \\
\hline & $(1.65)$ & $(0.16)$ & $(0.72)$ & $(2.19)$ & $(0.88)$ & $(1.07)$ & $(-0.13)$ & $(-1.33)$ \\
\hline \multirow[t]{2}{*}{$\operatorname{GDP}(t-3)$} & $-0.149^{*}$ & 0.0262 & -0.0283 & $-0.171^{* *}$ & 0.360 & -0.185 & -0.138 & 1.680 \\
\hline & $(-1.91)$ & $(0.45)$ & $(-0.29)$ & $(-2.31)$ & $(0.51)$ & $(-0.41)$ & $(-0.71)$ & $(0.59)$ \\
\hline \multirow[t]{2}{*}{$\pi(t-1)$} & -0.0848 & $0.516^{* * *}$ & 0.0382 & $0.383^{* *}$ & -1.041 & -0.879 & -0.348 & -3.582 \\
\hline & $(-0.68)$ & $(4.59)$ & $(0.24)$ & $(2.39)$ & $(-0.93)$ & $(-1.17)$ & $(-1.02)$ & $(-0.58)$ \\
\hline \multirow[t]{2}{*}{$\pi(t-2)$} & 0.284 & $0.304^{* * *}$ & $0.453^{* *}$ & -0.0724 & 1.369 & 0.392 & -0.382 & 7.263 \\
\hline & (1.63) & $(3.12)$ & $(2.00)$ & $(-0.53)$ & $(0.85)$ & $(0.57)$ & $(-0.94)$ & $(1.21)$ \\
\hline \multirow[t]{2}{*}{$\pi(t-3)$} & 0.00150 & 0.0430 & -0.196 & 0.00119 & $-2.528^{* *}$ & 0.0779 & 0.556 & 0.671 \\
\hline & $(0.01)$ & $(0.46)$ & $(-1.09)$ & $(0.01)$ & $(-2.32)$ & $(0.12)$ & $(1.49)$ & $(0.14)$ \\
\hline \multirow{2}{*}{ Loans $(t-1)$} & 0.0296 & 0.0244 & $1.008^{* * *}$ & -0.0409 & 0.586 & -0.409 & -0.0889 & $-8.019^{* *}$ \\
\hline & $(0.51)$ & $(0.59)$ & $(12.76)$ & $(-0.57)$ & $(0.89)$ & $(-1.13)$ & $(-0.48)$ & $(-2.00)$ \\
\hline \multirow[t]{2}{*}{ Loans $(t-2)$} & -0.0336 & -0.0436 & 0.0146 & 0.0514 & $-1.980^{* *}$ & 0.590 & $0.660^{* *}$ & $12.31^{* *}$ \\
\hline & $(-0.47)$ & $(-0.82)$ & $(0.12)$ & $(0.58)$ & $(-2.17)$ & $(0.99)$ & $(2.46)$ & $(2.32)$ \\
\hline \multirow[t]{2}{*}{ Loans $(t-3)$} & 0.0122 & -0.00252 & $-0.162^{* *}$ & 0.0342 & $1.363^{*}$ & -0.270 & $-0.411^{* *}$ & -3.545 \\
\hline & $(0.23)$ & $(-0.06)$ & $(-1.98)$ & $(0.58)$ & $(1.85)$ & $(-0.63)$ & $(-2.24)$ & $(-1.00)$ \\
\hline \multirow[t]{2}{*}{ Deposits $(t-1)$} & $0.0710^{*}$ & -0.0249 & 0.0913 & $0.954^{* * *}$ & 0.152 & 0.168 & -0.00324 & -0.0194 \\
\hline & $(1.67)$ & $(-0.96)$ & $(1.55)$ & $(8.49)$ & $(0.19)$ & $(0.64)$ & $(-0.03)$ & $(-0.01)$ \\
\hline \multirow[t]{2}{*}{ Deposits $(t-2)$} & $-0.126^{* *}$ & 0.0108 & -0.0944 & -0.0879 & 0.627 & 0.106 & 0.0304 & -1.393 \\
\hline & $(-2.56)$ & $(0.31)$ & $(-1.59)$ & $(-0.89)$ & $(0.78)$ & $(0.34)$ & $(0.19)$ & $(-0.43)$ \\
\hline \multirow[t]{2}{*}{ Deposits $(t-3)$} & 0.0642 & 0.0212 & $0.0796^{*}$ & $-0.183^{* *}$ & -0.211 & 0.254 & -0.0767 & 0.936 \\
\hline & $(1.41)$ & $(0.77)$ & $(1.90)$ & $(-2.06)$ & $(-0.38)$ & $(0.96)$ & $(-0.57)$ & $(0.37)$ \\
\hline \multirow[t]{2}{*}{ Spread $(t-1)$} & $-0.0182^{* * *}$ & -0.00381 & -0.00678 & 0.00984 & $0.795^{* * *}$ & $0.0697^{* * *}$ & -0.0208 & 0.516 \\
\hline & $(-4.08)$ & $(-1.17)$ & $(-1.26)$ & $(1.46)$ & $(11.17)$ & $(2.58)$ & $(-1.41)$ & (1.44) \\
\hline \multirow[t]{2}{*}{ Spread $(t-2)$} & $-0.00837^{*}$ & -0.00173 & 0.00176 & -0.00870 & 0.0876 & -0.0159 & 0.00408 & 0.564 \\
\hline & $(-1.69)$ & $(-0.48)$ & $(0.25)$ & $(-1.04)$ & $(0.90)$ & $(-0.45)$ & $(0.20)$ & $(1.30)$ \\
\hline \multirow[t]{2}{*}{ Spread $(t-3)$} & 0.00340 & 0.000285 & 0.00930 & -0.00161 & 0.0471 & -0.0163 & $-0.0519^{* * *}$ & $-0.919^{* *}$ \\
\hline & $(0.62)$ & $(0.07)$ & $(0.99)$ & $(-0.21)$ & $(0.64)$ & $(-0.41)$ & $(-2.83)$ & $(-2.48)$ \\
\hline \multirow[t]{2}{*}{ Wholesale $(t-1)$} & -0.00438 & -0.00687 & -0.0209 & -0.00771 & $0.574^{* * *}$ & $0.724^{* * *}$ & 0.0681 & 1.183 \\
\hline & $(-0.46)$ & $(-1.13)$ & $(-1.05)$ & $(-0.66)$ & $(2.69)$ & $(7.35)$ & $(1.54)$ & $(1.22)$ \\
\hline \multirow[t]{2}{*}{ Wholesale $(t-2)$} & $-0.0145^{*}$ & 0.00826 & 0.0109 & 0.0199 & $-0.532^{* * *}$ & 0.0267 & -0.0296 & -0.590 \\
\hline & $(-1.68)$ & $(1.17)$ & $(0.51)$ & $(1.09)$ & $(-3.42)$ & $(0.41)$ & $(-0.62)$ & $(-0.55)$ \\
\hline Wholesale $(t-3)$ & 0.0104 & 0.00482 & 0.00746 & 0.0122 & -0.0226 & -0.0770 & -0.0107 & -0.537 \\
\hline & $(1.42)$ & $(0.66)$ & $(0.44)$ & $(1.10)$ & $(-0.18)$ & $(-1.29)$ & $(-0.32)$ & $(-0.77)$ \\
\hline Leverage $(t-1)$ & 0.00847 & -0.0164 & 0.00608 & $0.0460^{*}$ & -0.188 & -0.000151 & $1.266^{* * *}$ & -0.562 \\
\hline & $(0.46)$ & $(-1.03)$ & $(0.20)$ & $(1.66)$ & $(-0.73)$ & $(-0.00)$ & $(18.13)$ & $(-0.50)$ \\
\hline Leverage $(t-2)$ & -0.0277 & 0.0309 & -0.0337 & -0.0550 & -0.487 & -0.119 & $-0.385^{* * *}$ & 0.616 \\
\hline & $(-1.26)$ & $(1.50)$ & $(-0.84)$ & $(-1.22)$ & $(-1.34)$ & $(-0.73)$ & $(-3.82)$ & $(0.38)$ \\
\hline Leverage $(t-3)$ & 0.0252 & -0.0133 & $0.0472^{*}$ & 0.0393 & 0.364 & 0.170 & -0.0829 & -0.732 \\
\hline & $(1.59)$ & $(-1.08)$ & $(1.68)$ & $(0.99)$ & $(1.25)$ & $(1.53)$ & $(-1.28)$ & $(-0.60)$ \\
\hline $\operatorname{ECB}(t-1)$ & 0.000376 & 0.000311 & 0.000194 & -0.0000850 & -0.0136 & -0.00319 & $0.00425^{* *}$ & $0.783^{* * *}$ \\
\hline & $(0.80)$ & $(0.97)$ & $(0.21)$ & $(-0.08)$ & $(-1.22)$ & $(-0.92)$ & $(2.21)$ & $(4.57)$ \\
\hline $\operatorname{ECB}(t-2)$ & -0.000502 & -0.000125 & $-0.00228^{* *}$ & 0.000528 & 0.0165 & -0.00314 & $-0.00384^{*}$ & -0.0465 \\
\hline & $(-0.99)$ & $(-0.43)$ & $(-1.98)$ & $(0.62)$ & (1.09) & $(-0.66)$ & $(-1.74)$ & $(-0.29)$ \\
\hline $\operatorname{ECB}(t-3)$ & -0.000494 & -0.0000632 & 0.00138 & 0.000132 & 0.00199 & 0.000831 & 0.00218 & $-0.141^{*}$ \\
\hline & $(-0.95)$ & $(-0.25)$ & $(1.62)$ & $(0.19)$ & $(0.21)$ & $(0.16)$ & $(1.15)$ & $(-1.91)$ \\
\hline$N$ & 352 & & & & & & & \\
\hline
\end{tabular}




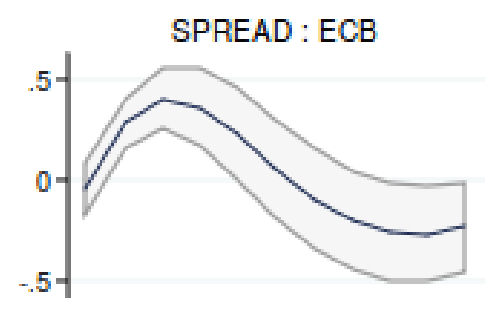

SPREAD : BOND

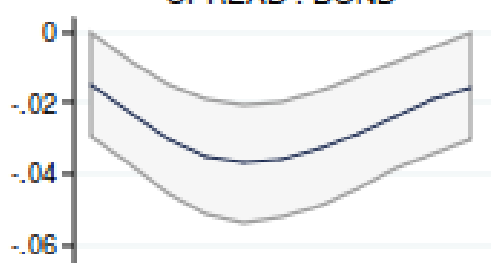

SPREAD : LEV

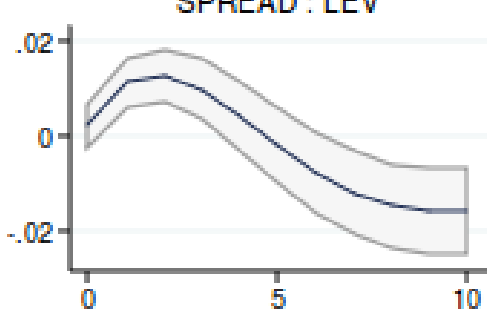

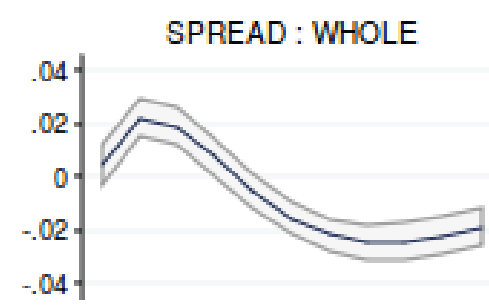

SPREAD : SPREAD

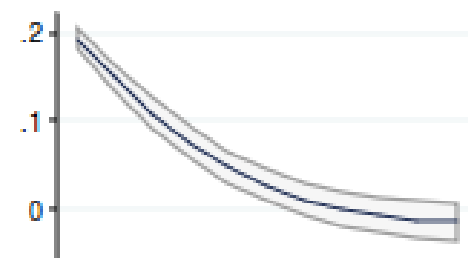

SPREAD : DEP

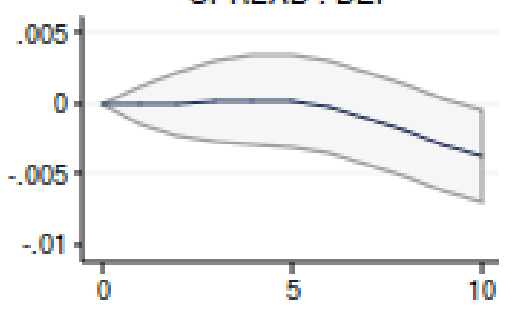

quarters

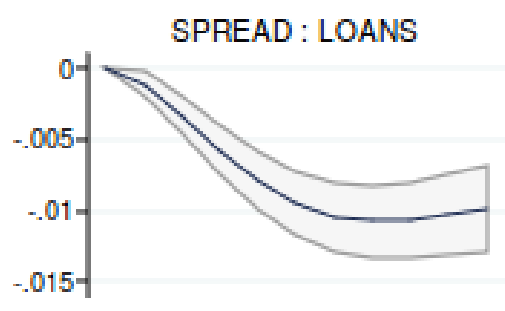

SPREAD : INFL

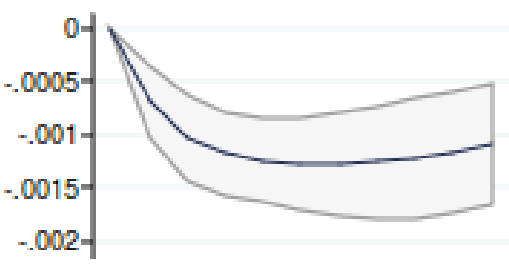

SPREAD : GDP

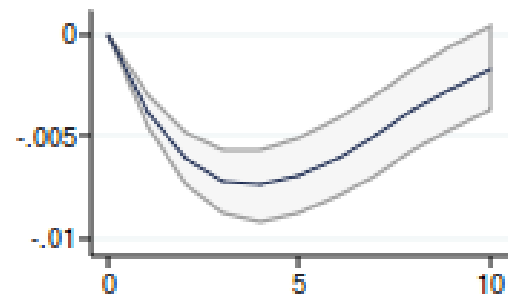

$90 \% \mathrm{Cl}$ Orthogonalized IRF

Fig. A5 Impulse response functions: Spread with Bond 

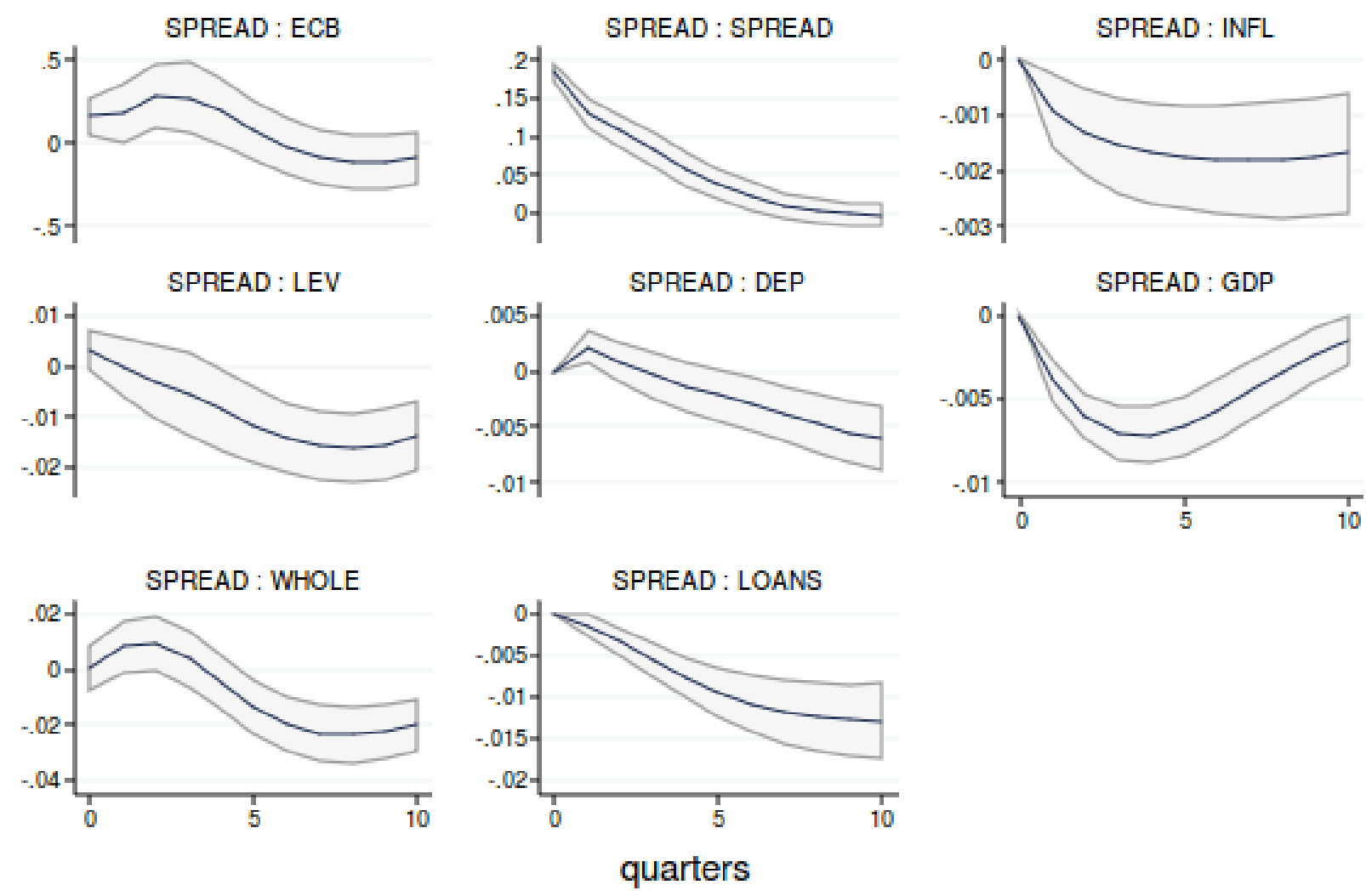

$90 \% \mathrm{Cl} \longrightarrow$ Orthogonalized IRF

Fig. A6 Impulse response functions: Spread with 2 lags 

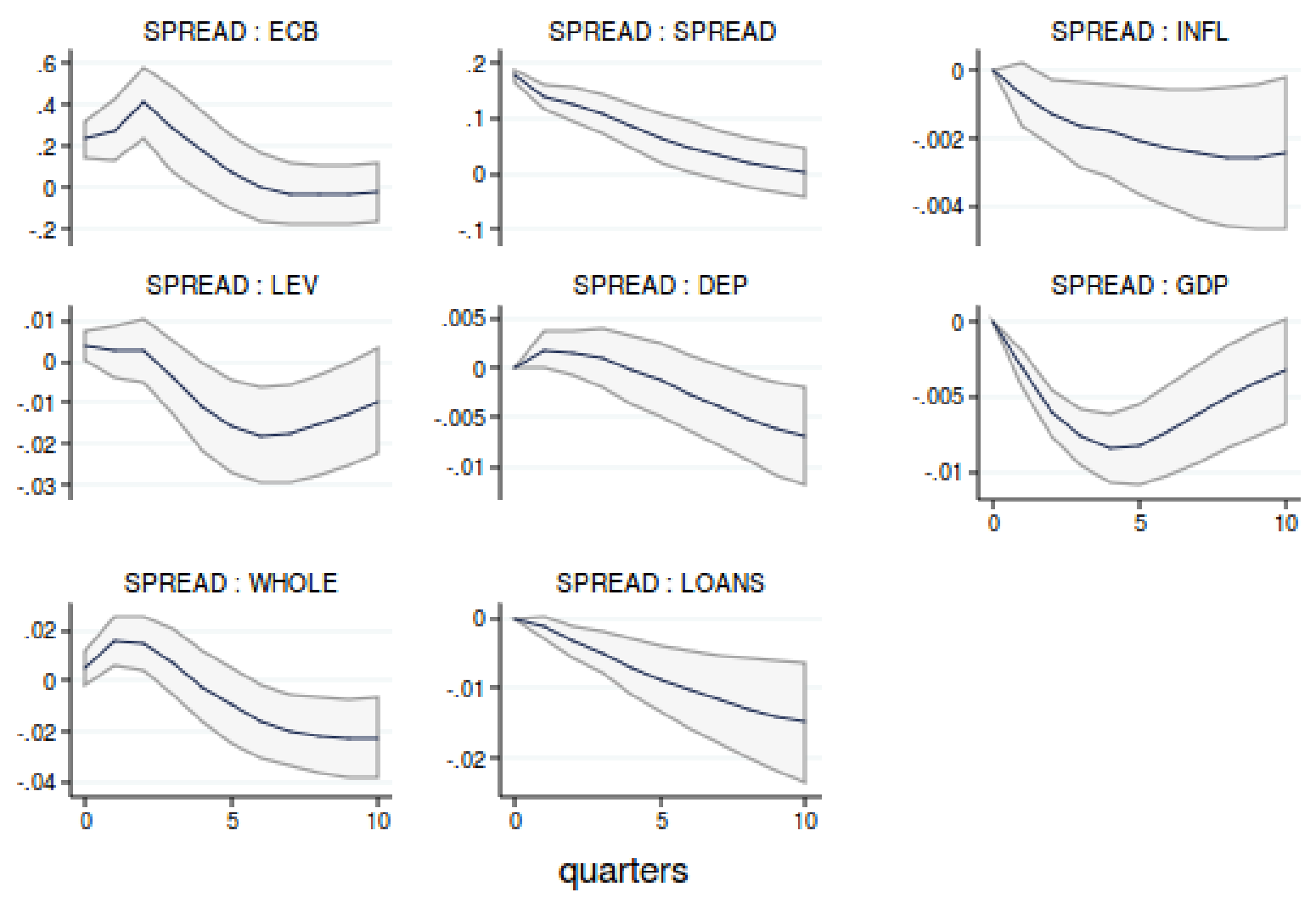

$90 \% \mathrm{Cl}$

Orthogonalized IRF

Fig. A7 Impulse response functions: Spread with 3 lags 

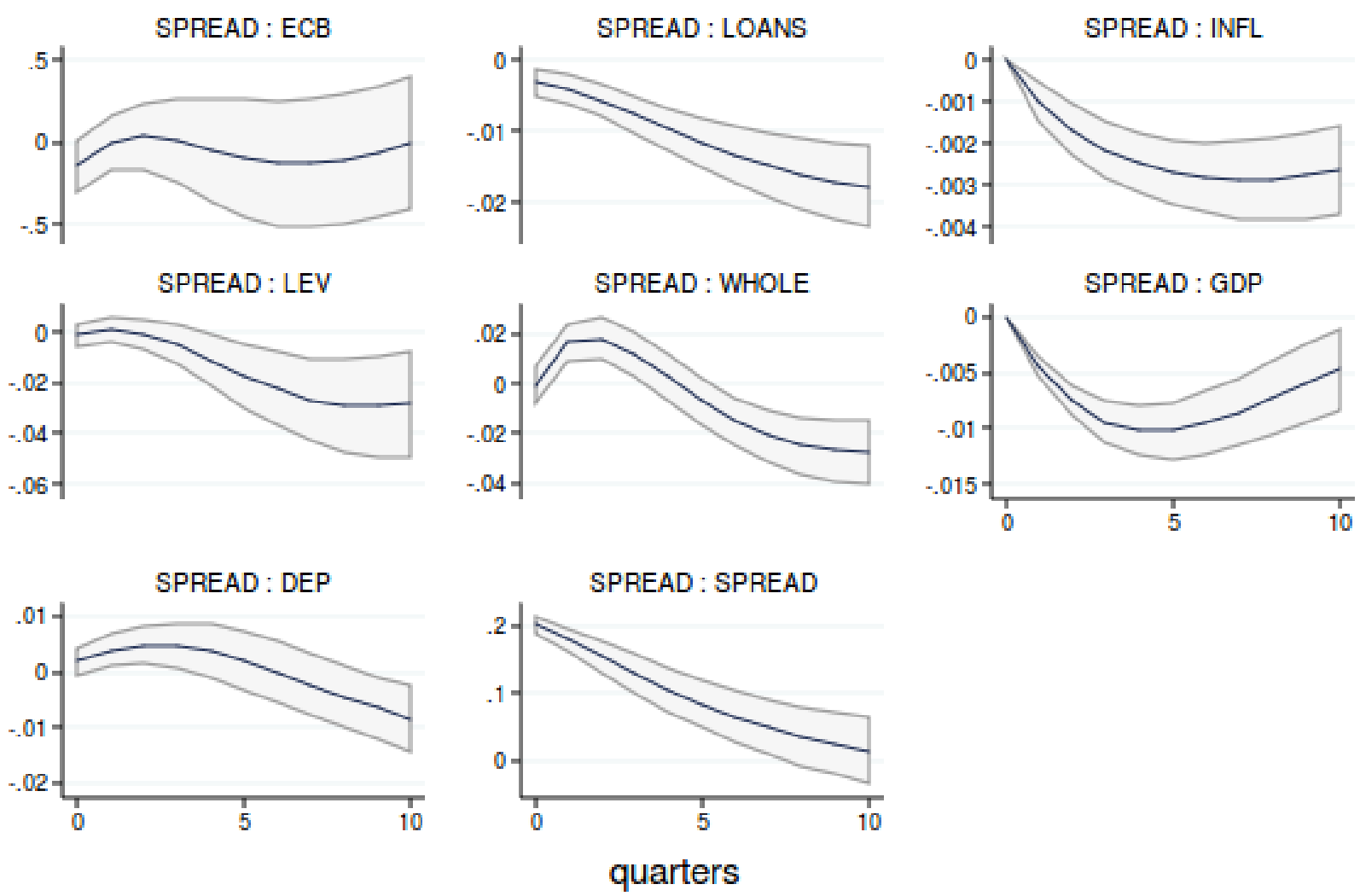

$90 \% \mathrm{Cl}$

Orthogonalized IRF

Fig. A8 Impulse response functions: Spread shock alternative order 
Table A9 Robustness: Panel cumulative response to a spread shock. Baseline refers to the 8 variable specification from Section 5, Alt. refers to alternative ordering of variables presented in 7.2 . Standard errors in parentheses

\begin{tabular}{llllllllc}
\hline & \multicolumn{2}{c}{ Deposits } & \multicolumn{2}{c}{ Wholesale } & \multicolumn{2}{c}{ ECB } & \multicolumn{2}{c}{ Loans } \\
\hline Quarter & Baseline & Alt. & Baseline & Alt. & Baseline & Alt. & Baseline & Alt. \\
\hline \hline 0 & 0.000 & 0.002 & 0.003 & -0.001 & -0.076 & -0.141 & 0.000 & -0.003 \\
& $(0.000)$ & $(0.001)$ & $(0.004)$ & $(0.005)$ & $(0.081)$ & $(0.096)$ & $(0.000)$ & $(0.001)$ \\
2 & 0.005 & 0.011 & 0.036 & 0.034 & 0.232 & -0.103 & -0.006 & -0.013 \\
& $(0.002)$ & $(0.005)$ & $(0.012)$ & $(0.013)$ & $(0.226)$ & $(0.283)$ & $(0.001)$ & $(0.003)$ \\
4 & 0.010 & 0.019 & 0.044 & 0.048 & 0.465 & -0.132 & -0.021 & -0.030 \\
& $(0.007)$ & $(0.009)$ & $(0.020)$ & $(0.022)$ & $(0.474)$ & $(0.555)$ & $(0.004)$ & $(0.006)$ \\
6 & 0.010 & 0.021 & 0.016 & 0.027 & 0.417 & -0.349 & -0.045 & -0.055 \\
& $(0.012)$ & $(0.015)$ & $(0.028)$ & $(0.031)$ & $(0.830)$ & $(0.915)$ & $(0.007)$ & $(0.011)$ \\
8 & 0.002 & 0.014 & -0.034 & -0.019 & 0.262 & -0.577 & -0.075 & -0.086 \\
& $(0.018)$ & $(0.020)$ & $(0.037)$ & $(0.040)$ & $(1.213)$ & $(1.288)$ & $(0.011)$ & $(0.016)$ \\
10 & -0.012 & -0.001 & -0.089 & -0.073 & 0.213 & -0.629 & -0.108 & -0.120 \\
& $(0.024)$ & $(0.025)$ & $(0.046)$ & $(0.049)$ & $(1.581)$ & $(1.635)$ & $(0.016)$ & $(0.021)$ \\
\hline \multirow{4}{*}{6} & & & & & & & &
\end{tabular}

